\title{
TELAFİ DERSİ ÇİZELGELEME PROBLEMİNİN (TDÇP) MATEMATIKKSEL MODELLE ÇÖZÜMÜ: GERÇEK BİR UYGULAMA
}

\author{
Ukbe Üsame UÇAR, Selçuk Kürşat İŞLEYEN \\ Gazi Üniversitesi, Mühendislik Fakültesi, Endüstri Mühendisliği Bölümü,06570, Ankara \\ ukbeusameucar@gmail.com , islevens@gazi.edu.tr
}

(Geliş/Received: 22.07.2015; Kabul/Accepted: 18.03.2016)

\begin{abstract}
ÖZET
Üniversitelerde bazı dersler dönem içerisinde; sempozyum, teknik gezi, öğretim elemanının akademik görevde olması, gibi çeşitli nedenlerden dolayı yapılamamaktadır. Eğitimin belirlenmiş olan müfredata göre akademik takvim içerisinde tamamlanabilmesi için yapılamayan derslerin sonraki haftalarda telafi edilmesi gerekmektedir. $\mathrm{Bu}$ durum klasik ders çizelgeleme probleminden farklı yeni bir ders çizelgeleme probleminin doğmasına neden olmaktadır. Bu problem, telafi dersi çizelgeleme problemi (TDÇP) olarak adlandırılmaktadır. Çalışmada bu problemin çözümü için yeni bir matematiksel model geliştirilmiş ve Gazi Üniversitesi Endüstri Mühendisliği Bölümü'nde uygulanmıştır. Mevcut bir zaman çizelgesinden hareketle çeşitli telafi dersi senaryoları hazırlanmış ve bu senaryolar geliştirilen matematiksel model yardımıyla çözülmüştür. Sonuçta derslerin uygun haftalara, günlere, saatlere ve dersliklere atandığı çizelgeler elde edilmiştir.
\end{abstract}

Anahtar Kelimeler: Üniversite ders çizelgeleme problemi, matematiksel modelleme, tamsayılı programlama, telafi dersi çizelgeleme problemi

\section{SOLVING MAKEUP COURSE TIMETABLING PROBLEM (MCTP) WITH MATHEMATICAL MODELLING: A REAL CASE APPLICATION}

\begin{abstract}
Several courses in university cannot be performed due to various reasons such as symposium, technical tour, academic mission of teaching staff in education period. The unrealized courses must makeup in subsequent weeks to complete the specified curriculum of education in academic calendar. This situation leads to a new timetabling problem different from Classic Course Timetabling Problem and it is named as Makeup Course Timetabling Problem. In this study, a new mathematical model is proposed to solve the stated problem and the model is applied on the Industrial Engineering Department of the Gazi University. Several test problem instances are obtained by identifying various makeup course scenarios in the existing timetabling and these instances are solved by using the proposed mathematical model. As a result, the schedules which the courses assigning the appropriate weeks, days, hours and classrooms are obtained.
\end{abstract}

Keywords: University course timetabling problem, mathematical modelling, integer programming, makeup course timetabling problem

\section{GIRISS (INTRODUCTION)}

Üniversitelerde kayıt tarihleri, ders başlama-bitiş tarihleri ve sinav tarihleri gibi akademik konular, eğitim öğretim yılının başında planlanarak akademik takvim oluşturulur. Akademik takvime bağlı kalarak ilgili akademik yılda, standart bir yapı içerisinde eğitim ve öğretim faaliyetlerinin gerçekleştirilmesi amaçlanmaktadır. Ancak akademik faaliyetler özellikle dersler çeşitli nedenlerden dolayı planlanan biçimde yapılamamaktadır. Üniversite ya da bölüm çapında düzenlenen sempozyumlar, yapılan teknik geziler, öğretim elemanına ilişkin durumlar (akademik görevde olması, hastalık, vb.), sınıf ve ders 
materyallerinde meydana gelen aksaklıklar bu nedenlerden bazılarıdır. Genel olarak üniversitelerde yapılamayan derslerin temel nedenleri aşağıdaki gibidir. Bir öğretim elemanının planlanmamış bir ameliyat veya rahatsızlığı (ayak kırılması, omuz çıkması vb.) nedeniyle ya da bayan ise hamileliğinden dolayı dönem içerisinde ders yapamaması ve bu derse atanan öğretim elemanı ile bu dersi alan öğrencilerin durumu dikkate alınarak ders programının yeniden çizelgelenmesi, olumsuz hava şartları nedeniyle eğitime ara verilmesi (24 Ocak 2016 - Kocaeli Üniversitesi [1]). Dönem içerisinde üniversitenin bulunduğu şehirde herhangi bir deprem nedeniyle binalarda hasar meydana gelmesi ve bu hasarın giderilmesi için öğrencilerin belirli bir süre tahliye edilmesi. Bu süre zarfinda eğitim duracak ve gerekli tahliye işlemi geçtikten sonra eğitim başlayacak ve müfredatın tamamlanması açısından yapılamayacak derslerin tekrar yapılması gerekecektir. Aksi halde öğrenciler dönem kaybedebilecektir. (Nepal'de 25 Nisan 2015 de meydana gelen depremden dolayı üniversitelerin mayısın ortasına kadar tatil edilmesi [2]). Çeşitli zamanlarda üniversitelerde siyasi olaylardan dolayı (gezi olayları vb.) dersler yapılamamakta ve üniversiteler, bu kaos ortamı geçinceye kadar birkaç gün ya da hafta için tatil edilebilmektedir. $\mathrm{Bu}$ süre zarfinda yapılamayan derslerin çizelgelenmesi gerekmektedir.(Ege Üniversitesinde eğitime verilen üç günlük ara [3]). Bazı zamanlar üniversiteler, bulunduğu ülkedeki seçim faaliyetlerinden dolayı tatil edilebilmektedir. (Türkiye'de 7 Haziran 2015 deki milletvekili seçimlerinden dolayı üniversitelerin tatil edilmesi [4]). Ülkelerde veya şehirlerde meydana gelen tsunami, sel, kasırga vb. nedeniyle eğitime ara verilmesi durumunda (Bangladeş'te hortum nedeniyle üniversitelerin tatil edilmesi [5]). Üniversitelerin bazı zamanlar çeşitli olimpiyatlara ev sahipliği yapmasından dolayı eğitimi erken tamamlaması (2011 Dünya Üniversiteler Arası Kış Olimpiyatları nedeniyle misafirlerin konaklaması için ögrenci yurtlarını tahsis etmesi ve öğrencilerin mağdur olmasını engellemek amacıyla da 15 haftalık eğitim dönemini 9 haftalık bir süre içerisinde tamamlamak zorunda kalmasi).

Eğitimin akademik takvim içerisinde belirlenmiş olan müfredata göre tamamlanması ve öğrencilerin mesleki yetersizliğe sahip olmasını engellemek amacıyla yapılamayan derslerin sonraki haftalar içerisinde telafi edilmesi gerekmektedir. Bu durum telafi derslerinin çizelgelenmesi problemini ortaya çıkarmıştır.

Telafi dersi çizelgeleme problemi (TDÇP), ilgili bölümde herhangi bir haftanın, herhangi bir gün ve saatinde yapilamayan dersin mevcut ders programı korunarak belirli kısıtlar altında akademik takvim kapsamında sonraki haftalarda uygun bir zaman periyodu ve derslik içerisinde çizelgelenmesi problemidir. TDÇP, üniversite ders çizelgeleme probleminin (ÜDÇP) bir uzantısıdır. ÜDÇP, her eğitim dönemi başında karşılaşılan, derslerin belirli kısitlar altında uygun zaman periyodu, öğretim elemanı ve dersliklere atanmasının gerçekleştirildiği NP-Tam [6] bir problemdir. ÜDÇP için literatürde birçok çalışma mevcuttur. Ancak her eğitim kurumunun kendine özgü yapısı, kısıtları ve kuralları farklı olduğundan uygulanabilir standart bir çözüm yaklaşımı geliştirilememiştir. Literatürde ÜDÇP çözümü için; Matematiksel Modelleme [7-14], Yapay Ar1 Kolonisi Algoritmas1 [15], Genetik Algoritma [16], Tavlama Benzetimi [17], Kisıt Programlama [18, 19], Hibrit Metotlar [20-29], Parçacık Sürü Optimizasyonu [30], Göçmen Kuşlar Optimizasyon Algoritması [31] gibi birçok yaklaşım önerilmiştir.

Telafi dersi çizelgeleme problemi için bilindiği kadarıyla literatürde iki çalışma bulunmaktadır. Fakat önerdiğimiz çalışma, tanım ve kapsam bakımından bu iki çalışmadan ayrılmakta ve telafi dersi çizelgeleme probleminin farklı şekilde yorumlanmasına neden olmaktadır. Bu çalışmalardan birincisi Shimazaki ve ark. [32] yaptıkları çalışmayken, ikincisi ise "Chaudry ve ark. [33]" yaptıkları çalışmadır. Shimazaki ve ark. [32], yaptıkları çalışmada telafi dersi çizelgeleme problemini, öğretim elemanlarının istekleri doğrultusunda yapılamayan derslerin, normal eğitim periyodunun dişında, kendileri için ayrılmış olan 5-6 günlük bir zaman dilimi içerisinde çizelgelenmesi şeklinde ifade etmişlerdir. Bu zaman dilimi içerisinde mevcut ders programı dikkate alınmamış, yalnızca yapılamayan dersler tamamen boş zaman dilimlerinde çizelgelenmeye çalışılmış̦tı. Boş zaman dilimlerinden kasıt herhangi bir dersin, öğretim elemanının ve dersliğin atanmadığ 1 zaman dilimleridir. Bizim çalışmamızda ise telafi derslerinin çizelgelenmesi için normal eğitim periyodu dışında herhangi bir zaman dilimi ayrılmamıştır. Çizelgeler, yapılamayan derslerin, eğitim periyodu içerisinde (14 ya da 15 hafta) sonraki haftalarda çizelgelenmesi esas alınarak oluşturulmaktadır. Atama yapılırken de her bir haftadaki mevcut ders programı dikkate alınmış, yapılamayan dersler, telafi dersini alan öğrenciler, dersi veren öğretim elemanları ve mevcut ders programı ile çakıştırmada çizelgelemeye çalışmıştır. İki çalışmada ele alınan sıkı kısıtlar Tablo 1'de, esnek kısıtlar ise Tablo 2'de belirtilmiştir.

$\mathrm{Bu}$ çalışma dışında literatürde telafi dersi çizelgeleme problemi ile ilgili bir çalışma daha tespit edilmiştir. Chaudry vd. [33], yaptıkları çalışmada Telafi Ders Çizelgeleme Problemini, CBR (Case Based Reason) ve tabu arama yöntemi ile çözmeye çalışmışlardır. Tabu arama yöntemi ile optimum çözümü bulmaya çalışlırlarken, CBR yöntemi ile de çözümleri iyileştirilmeye çalışılmışlardır. Probleme mevcut bir zaman çizelgesi girilmiş ve bir haftalık bir süre içerisinde yalnızca 15 adet dersin çizelgelendiği ders çizelgeleri oluşturulmuştur. Haftalık zaman 
Tablo 1. İki çalışmada ele alınan sıkı kısıtlar (Strict constraints dealt with in two studies)

\begin{tabular}{|c|c|c|}
\hline Kisit & $\mathrm{Bu}$ çalışma & Shimazaki vd. [32] \\
\hline 1 & $\begin{array}{l}\text { Akademik takvim kapsamında sekizinci hafta } \\
\text { vize haftası olarak belirlenmiştir. Bu hafta } \\
\text { içerisinde herhangi bir telafi dersinin yapılmasına } \\
\text { izin verilmemektedir. }\end{array}$ & Her ders bir zaman boşluğuna atanmalıdır. \\
\hline 2 & $\begin{array}{l}\text { Telafi dersleri mevcut ders programı koruncak } \\
\text { şekilde uygun hafta, gün, saat ve dersliklere } \\
\text { atanmalıdır. }\end{array}$ & $\begin{array}{l}\text { Bir ders, belirlenen zaman boşluklarında ardışık } \\
\text { bir şekilde çizelgelenmelidir. }\end{array}$ \\
\hline 3 & $\begin{array}{l}\text { Bir telafi dersi aynı hafta, gün ve saat içerisinde } \\
\text { yalnızca bir derslikte yapılabilir. }\end{array}$ & $\begin{array}{l}\text { Bir öğretim elemanı aynı zaman boşluğu } \\
\text { içerisinde ikiden fazla derse giremez. }\end{array}$ \\
\hline 4 & $\begin{array}{l}\text { Bir şubeye aynı hafta, gün ve saat içerisinde } \\
\text { yalnız bir telafi dersi atanabilir. }\end{array}$ & $\begin{array}{l}\text { Bir öğretim elemanı aynı derslikte iki tane ders } \\
\text { işleyemez. }\end{array}$ \\
\hline 5 & $\begin{array}{l}\text { Bir öğretim elemanı aynı hafta, gün ve saat } \\
\text { içerisinde tek bir şubeye ve tek bir dersliğe } \\
\text { atanabilir. }\end{array}$ & Derslik kapasitesi aşılamaz. \\
\hline 6 & $\begin{array}{l}\text { Bir günde telafi dersine ait en fazla üç kredi } \\
\text { yapılabilir ve eğitim yalnızca hafta içi } \\
\text { yapılmaktadır. }\end{array}$ & Yapay zaman boşluklarına atama yapılamaz. \\
\hline 7 & $\begin{array}{l}\text { Zorunlu derslerin seçmeli derslerle çakışmasına } \\
\text { izin verilmemektedir. }\end{array}$ & \\
\hline
\end{tabular}

Tablo 2. İki çalıșmada ele alınan esnek kısıtlar (Flexible constraints dealt with in two studies)

\begin{tabular}{|c|c|c|}
\hline Kisit & Bu çalışma & Shimazaki vd. [32] \\
\hline 1 & $\begin{array}{l}\text { Derslik kapasitesinin aşılmaması } \\
\text { istenmektedir. }\end{array}$ & $\begin{array}{l}\text { Bir ders, tercih edilme değerine göre bir zaman } \\
\text { boșluğuna atanmalıdır. }\end{array}$ \\
\hline 2 & $\begin{array}{l}\text { Telafi derslerine ait kredilerin aynı hafta ve } \\
\text { gün içerisinde, aynı dersliklerde, ardışık } \\
\text { saatlerde yapılması istenmektedir. }\end{array}$ & $\begin{array}{l}\text { Bir öğrenci aynı zaman boşluğu içerisinde ikiden } \\
\text { fazla derse atanmamalıdır. }\end{array}$ \\
\hline 3 & $\begin{array}{l}\text { İlgili bölümde dersler en az iki krediye } \\
\text { sahiptir ve aynı hafta ve gün içerisinde ilgili } \\
\text { derse ait en az iki kredinin çizelgelenmesi } \\
\text { istenmektedir. }\end{array}$ & $\begin{array}{l}\text { Birbirine yakın zamanlarda çizelgelenmesi istenen } \\
\text { dersler, yakın zaman dilimlerinde } \\
\text { çizelgelenmelidir. }\end{array}$ \\
\hline 4 & $\begin{array}{l}\text { Telafi dersine ait tüm kredilerin belirlenen s1k1 } \\
\text { kısıtlardan dolayı çizelgelenmesi mümkün } \\
\text { olmayabilir. Çizelgede olabildiğince telafi } \\
\text { dersine ait tüm kredilerin yapılması } \\
\text { amaçlanmaktadır. Örneğin zorunlu kalınırsa } 3 \\
\text { kredilik bir dersin 2+1 saatlik blok şeklinde } \\
\text { işlenmesine müsaade edilmektedir. }\end{array}$ & $\begin{array}{l}\text { Birbirinden uzak zamanlarda çizelgelenmesi } \\
\text { istenen dersler, ayrık zamanlarda çizelgelenmelidir. }\end{array}$ \\
\hline 5 & & $\begin{array}{l}\text { Akşam saatlerine (11. ve 12. zaman boşluklarına) } \\
\text { atama yapılmamalıdır. }\end{array}$ \\
\hline 6 & & $\begin{array}{l}\text { İlk olarak öncelik değeri yüksek olan telafi dersleri } \\
\text { çizelgelenmelidir. }\end{array}$ \\
\hline
\end{tabular}

dilimlerinin dikkate alınmaması, yalnızca belirli dersler için tek bir hafta içerisinde çizelgelerin oluşturulması ve problemin sezgisel bir yöntemle çözülmeye çalışması Chaudry vd. [33] yapmış olduğu çalışmayı, bu çalışmadan ayırmaktadır.

$\mathrm{Bu}$ çalışmada Gazi Üniversitesi Endüstri Mühendisliği Bölümünün hem lisans ders programının oluşturulması hem de sonrasında çeşitli senaryolar altında telafi derslerinin çizelgelenmesi için 2 yeni matematiksel model önerilmiş ve çözümleri sunulmuştur. Bu çalışma, Telafi Dersi Çizelgeleme Problemini, mevcut ders çizelgesi ve haftalık zaman dilimlerini dikkate alınarak yeniden tanımlanması ve problemin çözümü için önerilen matematiksel model nedeniyle literatürdeki diğer çalışmalardan ayrılmaktadır. Çalışmanın devamı şu şekilde organize edilmiştir. Bölüm 2'de uygulama yapılan yere ilişkin ders çizelgeleme problemi tanımlanarak, problemin çözümü için matematiksel model önerilmiştir. Matematiksel model çözülerek Lisans ders programı oluşturulmuştur. Bölüm 3'de TDÇP'e ilişkin genel özellikler ortaya konmuş ve telafi derslerinin çizelgelenmesi için geliştirilen matematiksel model detaylı olarak anlatılmıştır. 4. bölümde farklı senaryolar üretilerek TDÇP için uygulama çalışması gerçekleştirilmiş, son bölümde ise elde edilen sonuçlar tartışılmıştır. 


\section{2. ÜNIVERSITE DERS ÇIZELGELEME PROBLEMİ (ÜDÇP) VE MATEMATIKSEL MODELI (UNIVERSITY COURSE TIMETABLING PROBLEM (UCTP) AND MATHEMATICAL MODEL)}

Üniversite ders çizelgeleme problemi, ilgili eğitim kurumunun fiziki ve idari koşulları altında derslerin, uygun zaman dilimi ve dersliklere atanması problemidir. Çoğu eğitim kurumunda bu problem ilgili personeller tarafindan el ile hazırlanmakta ve haftalarca sürebilmektedir. Ayrıca üniversite ders çizelgeleme problemi uygulama açısından yaklaşık 6 aylık bir dönemi kapsadığından taktiksel seviyede karar vermeye girmektedir. Problemde sağlanması gereken birçok kısıt, ulaşıılmak istenen birçok amaç bulunmaktadır. $\mathrm{Bu}$ kısıt ve amaçlar eğitim kurumlarını yapısına göre farklılık gösterebilmektedir. Ders çizelgeleme problemi için ele alınan kısıtlar, sıkı ve esnek kısıtlar olmak üzere ikiye ayrılmaktadır. Sik1 kısitlar ihlal edilmesi mümkün olmayan kısıtlardır. Öğretim elemanlarının çakışmaması, derslik kapasitelerinin aşılmaması, bilgisayar uygulaması gerektiren derslerin bilgisayar laboratuvarında yapılması bu kisitlardan bazılarıdır. Esnek kısitlar ise ihlal edilmesi istenmeyen fakat ihlal edilse bile çözümün uygunluğunu bozmayan kısttlardır. Öğlen saatine ders atanmaması, seçmeli derslerin çakışmaması, derslerin aynı derslik binası içinde yapılması, öğretim elemanlarının tercih ettiği zaman dilimlerine atanması örnek esnek kısıtlardan bazılarıdır. Esnek kısıtların karşılanması amaç fonksiyonuna olumlu yönde etki yapmaktadır.

Tablo 3. Üniversite Ders Çizelgeleme Problemi kapsamında ele alınan sikı kisitlar ( Hard constraints discussed under University Course Timetabling Problem)

- Bilgisayar laboratuvarına yalnızca bilgisayar uygulamas1 gerektiren dersler atanabilir.

- Bir öğretim elemanı aynı gün ve saat içerisinde yalnızca bir şubeye ders verebilir.

- Bir dersliğe herhangi bir gün ve saatte yalnızca bir ders atanabilir.

- Bir ders bir gün içerisinde yalnızca bir saatte yapilabilir.

- Bir şubeye aynı gün ve saat içerisinde yalnızca bir ders atanabilir.

- Zorunlu derslerin seçmeli derslerle çakışmasına izin verilmemektedir.

- Bir dersin tüm kredileri o hafta içerisinde yapilmalidir.

- İlgili bölümde dersler en az iki krediye sahiptir. Bir günde ilgili derse ait en az iki kredinin en fazla üç kredinin çizelgelenmesi gerekmektedir. Üç krediden daha fazla krediye sahip olan dersler farklı günlerde çizelgelenecektir.

- Ardışık olarak çizelgelenmesi gereken dersler, aynı gün ve derslik içerisinde ardışı saatlerde çizelgelenmelidir.

- Dersi alan öğrenci sayısı, derslik kapasitesini aşmamalıdır. Eğitim yalnızca hafta içi yapılmaktadır.
Gazi Üniversitesi Endüstri Mühendisliği Bölümü 2014-2015 Bahar Dönemi Lisans Ders Programı Çizelgeleme Problemi uygulama kapsamında ele alınan problemdir. Bölümde her bir sinıf normal öğretim ve ikinci öğretim olmak üzere ikiye ayrılmaktadır. Normal öğretim ve ikinci öğretimde kendi içerisinde iki ayrı şubeye ayrılmaktadır. Genel olarak bir dönemde bir sınıfa ait dört şube olmak üzere toplamda 16 adet şubeye, 43 tane öğretim elemanı tarafindan, 8 adet derslikte, 08:30 ile 19:20 saatleri arasında eğitim verilmektedir. Dersler 50' şer dakikalık zaman periyodlarından oluşmakta ve derslerin çizelgeleneceği 11 adet zaman boşluğu bulunmaktadır. İlgili bölümde ders çizelgeleme problemi kapsamında ele alınan sıkı kısitlar Tablo 3'de belirtilmiştir:

İkinci, üçüncü ve dördüncü sınıfın aldığı seçmeli derslerin, kendi içlerinde birbiriyle çakışmama durumu ise esnek kısıt olarak değerlendirilmiştir. ÜDÇP çözümü için Köçken vd. [9] geliştirmiş oldukları matematiksel model temel alınmış üzerinde çeşitli değişiklikler yapılarak kullanılmıştır. Yapılan değişiklikler ve eklenen özellikler aşağıda verilmiştir.

Köçken vd. [9] yapmış oldukları çalışmada iki ve üç saatlik dersleri tek oturumluk dersler, dört ve beş saatlik dersler ise iki oturumluk dersler olarak ayrılmaktadır. Bizim çalışmamızda kredi ayrımı yapılmaksızın dersler bir bütün olarak dikkate alınmakta, model ilgili kısıtlar doğrultusunda dersleri 4 saatlik dersleri $2+2$ şeklinde, 5 saatlik dersleri ise $3+2$ şeklinde ayırıp uygun zaman boşluklarına atamaktadır. Köçken vd. [9] yapmış oldukları çalışmada öğrenci grupları için seçmeli ders çakışmaları esnek kısıt olarak dikkate alınmışken, bizim çalışmamızda 2 . 3. ve 4 . sınıflar için tüm zorunlu derslerin, seçmeli derslerle çakışmasına izin verilmemiş, her bir sınıftaki seçmeli derslerin kendi aralarındaki çakışmaları minimize edilmeye çalışılmıştır. İki modelde de ortak kullanılan değişken " $x_{i, j, m, n}$ " değişkenidir. " $g s_{i, m, n}$ ", " $d c_{i, j}$ ", " $u c_{i, j}$ ", " $i c_{i, j}$ " değişkenleri ise diğer çalışmadan farklı olarak model içinde kullanılan değişkenlerdir.

Model içerisinde kullanılan indisler aşağıdaki gibidir.

$\begin{array}{rlll}\mathrm{i}= & \text { Gün indisi } & \mathrm{i} \in \mathrm{I}=\left\{1,2, . ., \mathrm{i}_{\text {son }}\right\} \\ \mathrm{j}= & \text { Zaman indisi } & \mathrm{j} \in \mathrm{J}=\left\{1,2, . ., \mathrm{j}_{\text {son }}\right\} \\ \mathrm{m}= & \text { Ders indisi } & \mathrm{m} \in \mathrm{M}=\left\{1,2, . ., \mathrm{m}_{\text {son }}\right\} \\ \mathrm{n}= & \text { Derslik indisi } & \mathrm{n} \in \mathrm{N}=\left\{1,2, . ., \mathrm{n}_{\text {son }}\right\} \\ \mathrm{k}= & \text { Sinıf indisi } & \mathrm{k} \in \mathrm{K}=\left\{1,2, . ., \mathrm{k}_{\text {son }}\right\} \\ \mathrm{v}= & \text { Öğretim zamanı } & \mathrm{v} \in \mathrm{V}=\left\{1,2, . ., \mathrm{v}_{\text {son }}\right\} \\ & \text { indisi (normal ve } & \\ & \text { ikinci öğretim) } & \\ \mathrm{q}= & \text { Şube indisi } & \mathrm{q} \in \mathrm{Q}=\left\{1,2, . ., \mathrm{q}_{\text {son }}\right\} \\ \mathrm{g}= & \text { Öğretim elemanı } & \mathrm{g} \in \mathrm{G}=\left\{1,2, . ., \mathrm{g}_{\text {son }}\right\} \\ & \text { indisi } & \end{array}$


Lisans derslerinin çizelgelenmesinde kullanılan kümeler aşağıdaki gibidir.

$$
\begin{aligned}
& \mathrm{Z}=\text { iki ve üç krediye sahip m dersleri } \\
& \mathrm{R}=\text { üç ve beş krediye sahip } \mathrm{m} \text { dersleri } \\
& \mathrm{L}=\text { dört ve beş krediye sahip } \mathrm{m} \text { dersleri } \\
& \mathrm{G} \quad=\text { bilgisayar laboratuvarında yapılması } \\
& \text { gereken } \mathrm{m} \text { dersleri } \\
& \mathrm{T}=\text { bilgisayar laboratuvarında } \\
& \text { yapılmaması gereken } \mathrm{m} \text { dersleri } \\
& \mathrm{U}=\text { atıl } \mathrm{t} \text { zamanları } \\
& \mathrm{P} \quad=\text { atama yapilacak zamanlar } \\
& \mathrm{M}_{\mathrm{g}}=\mathrm{g} \text { öğretim elemanının vereceği } \mathrm{m} \\
& \text { dersleri } \\
& \mathrm{M}_{\mathrm{k}, \mathrm{v}, \mathrm{q}}=\mathrm{k} \text {. sınıf, v. öğretim, q. şubenin alacağ } \\
& \mathrm{m} \text { dersleri } \\
& \mathrm{B}_{\mathrm{k}}=\mathrm{k} \text {. sınıfin alabileceği } \mathrm{m} \text { seçmeli dersleri } \\
& \mathrm{O}_{\mathrm{k}}=\mathrm{k} \text {. sınıfin alacağ } 1 \text { temel dersler }
\end{aligned}
$$

Lisans derslerinin çizelgelenmesinde kullanılan parametreler aşağıdaki gibidir.

$\mathrm{W}_{\mathrm{m}}=\mathrm{m}$ dersine ait kredi sayısı

$\mathrm{d}_{\mathrm{m}} \quad=\quad \mathrm{m}$ dersini alan öğrenci sayısı

$\mathrm{r}_{\mathrm{n}} \quad=\mathrm{n}$ dersliğinin kapasitesi

Lisans derslerinin çizelgelenmesinde kullanılan değişkenler aşağıdaki gibidir.

$\mathrm{x}_{\mathrm{i}, \mathrm{j}, \mathrm{m}, \mathrm{n}}=1, \mathrm{~m}$. ders, i. gün, $\mathrm{j}$. saatte $\mathrm{n}$. dersliğe atanırsa

$$
\begin{aligned}
& 0 \text {, diğer durumda } \\
& \mathrm{gs}_{\mathrm{i}, \mathrm{m}, \mathrm{n}}=1, \mathrm{~m} \text {. ders, } \mathrm{i} \text {. gün, } \mathrm{n} \text {. derslikte yapılırsa } \\
& 0 \text {, diğer durumda } \\
& \mathrm{dc}_{\mathrm{i}, \mathrm{j}}=\mathrm{i} \text {. gün, j. saatte, dördüncü sinıftaki } \\
& \text { seçmeli derslere ait çakışan kredi sayısı } \\
& \mathrm{uc}_{\mathrm{i}, \mathrm{j}}=\mathrm{i} \text {. gün, } \mathrm{j} \text {. saatte, üçüncü sınıftaki seçmeli } \\
& \text { derslere ait çakışan kredi sayısı } \\
& \mathrm{ic}_{\mathrm{i}, \mathrm{j}}=\mathrm{i} \text {. gün, } \mathrm{j} \text {. saatte, ikinci sınıftaki seçmeli } \\
& \text { derslere ait çakışan kredi sayısı }
\end{aligned}
$$

Modeldeki amaç fonksiyonu (2.1) uygun ders programı oluşturulurken seçmeli derslerin çakışma saysını en aza indirerek öğrencilerin seçenek sayısını arttırmaktır. Kısıt kümesi (2.2) ve (2.3) laboratuvar da yapılması gereken derslerin atanmalarını sağlar. Kısıt kümesi (2.4) öğretim elemanı-derslik atamasını kısıt kümeleri (2.5) ve (2.6) ise ders-derslik atamalarını gerçekleştirir. Kısıt kümesi (2.6), bir dersin aynı anda birden fazla dersliğe atanmasını, kısıt kümesi (2.7), bir şubenin aynı gün ve saat içerisinde, birden fazla ders ve dersliğe atanmasını engeller. Kısıt kümesi (2.8), bir şubenin zorunlu dersleri ile seçmeli derslerinin çakışmamasını sağlarken, kısıt kümeleri (2.9), (2.10) ve (2.11) her bir sinıftaki seçmeli derslerin birbiriyle çakışmasını engelleyen esnek bir kısıttır. Kısıt kümesi (2.13), (2.14) ve (2.15) sırasıyla iki ve üç krediye sahip derslerin ardışık zaman dilimlerinde ve aynı dersliklerde çizelgelenmesini sağlar. Bu çalışmada iki ve üç krediye sahip olan dersler tek oturumluk derslerken, dört kredilik dersler

Lisans derslerinin çizelgelenmesinde kullanılan kısıtlar ve amaç fonksiyonu aşağıdaki gibidir.

$$
\begin{aligned}
& \min \sum_{i \in I} \sum_{j \in J}\left(d c_{i, j}+u c_{i, j}+i c_{i, j}\right) \\
& \sum_{i \in I} \sum_{j \in J} x_{i, j, m, n}=w_{m} \quad \forall m \in G, n \in\{1\} \\
& g s_{i, m, n}=0 \quad \forall i \in I, \forall m \in T, \forall n \in\{1\} \\
& \sum_{m \in M_{g}} \sum_{n \in N} x_{i, j, m, n} \leq 1 \quad \forall i \in I, \forall j \in J, \forall g \in G \\
& \sum_{m \in M} x_{i, j, m, n} \leq 1 \quad \forall i \in I, \forall j \in J, \forall n \in N \\
& \sum_{n \in N} x_{i, j, m, n} \leq 1 \quad \forall i \in I, \forall j \in J, \forall m \in M \\
& \sum_{m \in M_{k, v}, q} \sum_{n \in N} x_{i, j, m, n} \leq 1 \quad \forall i \in I, \forall j \in J, \forall k \in K, \forall v \in V, \forall q \in Q \\
& \sum_{n \in N}\left(x_{i, j, m \in B_{k}, n}+x_{i, j, m \in O_{k}, n}\right) \leq 1 \quad \forall i \in I, \forall j \in J, \forall k \in K \\
& \sum_{m \in B_{k}} \sum_{n \in N} x_{i, j, m, n} \leq 1+d c_{i, j} \quad \forall i \in I, \forall j \in J, k \in\{4\} \\
& \sum_{m \in B_{k}} \sum_{n \in N} x_{i, j, m, n} \leq 1+u c_{i, j} \quad \forall i \in I, \forall j \in J, k \in\{3\} \\
& \sum_{m \in B_{k}} \sum_{n \in N} x_{i, j, m, n} \leq 1+i c_{i, j} \quad \forall i \in I, \forall j \in J, k \in\{2\} \\
& \sum_{i \in I} \sum_{j \in J} \sum_{n \in N} x_{i, j, m, n}=w_{m} \quad \forall m \in M \\
& x_{i, j, m, n}=0 \quad \forall i \in I, \forall j \in U, \forall m \in M, \forall n \in N \\
& x_{i, j+1, m, n}-x_{i, j, m, n}-x_{i, j+2, m, n} \leq 0 \quad \forall i \in I, \forall j \in P, \forall m \in M, \forall n \in N \\
& x_{i, j+1, m, n}-x_{i, j, m, n}-x_{i, j+3, m, n} \leq 0 \quad \forall i \in I, \forall j \in P, \forall m \in R, \forall n \in N \\
& \sum_{i \in I} \sum_{n \in N} g s_{i, m, n}=2 \quad \forall m \in L \\
& \sum_{i \in I} \sum_{n \in N} g s_{i, m, n}=1 \quad \forall m \in Z \\
& \sum_{j \in P} x_{i, j, m, n} \leq 3 \times g s_{i, m, n} \quad \forall i \in I, \forall m \in M, \forall n \in N \\
& \sum_{j \in P} x_{i, j, m, n} \geq 2 \times g s_{i, m, n} \quad \forall i \in I, \forall m \in M, \forall n \in N \\
& \sum_{j \in P} \sum_{n \in N} x_{i, j, m, n} \leq 3 \quad \forall i \in I, \forall m \in M \\
& x_{i, j, m, n} \times d_{m} \leq r_{n} \quad \forall i \in I, \forall j \in J, \forall m \in M, \forall n \in N \\
& x_{i, j, m, n} \in\{0,1\} \quad \forall i \in I, \forall j \in J, \forall m \in M, \forall n \in N \\
& g s_{i, m, n} \in\{0,1\} \quad \forall i \in I, \forall m \in M, \forall n \in N \\
& d c_{i, i}, u c_{i, j}, i c_{i, i} \geq 0 \quad \forall i \in I, \forall j \in J
\end{aligned}
$$


iki oturumluk dersler olarak nitelendirilmiştir. İki oturuma sahip olan derslerin farklı günlerde çizelgelenmesi gerekmekte ve bu şart kısıt kümesi (2.16) ile sağlanmaktadır. Kısıt kümesi (2.17) tek oturuma sahip derslerin tek bir günde çizelgelenmesini sağlar. Kısıt kümesi (2.18), (2.19) ve (2.20) ders-derslik ve ders kredisi ilişkisini sağlarken aynı zamanda 4 saatlik derslerin $2+2$ şeklinde ve 5 saatlik derslerin $2+3$ şeklinde ayrılmasını gerçekleştirirler. Son olarak (2.21) kısıdı ile bir dersliğe kapasitesinden fazla öğrenci atanması engellenir. Problemde çizelgelenmesi gereken 242 kredi, 78 adet ders, 16 adet şube ve 43 adet öğretim elemanı vardır. Geliştirilen model 47011 değişken ve 151120 adet kısıttan oluşmaktadır. Model, 4 GB RAM, 3.20 GHz işlemcili bir bilgisayarda, IBM ILOG CPLEX Optimization Studio12.6.0.0 programında 2 saat koşturulmuş, amaç fonksiyon değeri 9 ve Gap değeri \%66,67 olan bir çözüm çözülmüştür. Elde edilen sonuçlar Tablo10, Tablo 11, Tablo 12, Tablo 13 ve Tablo 14 olarak ekte belirtilmiştir. Örneğin Tablo 10'da "Pazartesi” günü, “404” numaralı derslikte ,"08:30-11:20” saatleri arasında "ENM467(3)(3)(1)" ifadesi atanmıştır. "ENM467(3)(3)(1)" ifadesinde, "ENM" ifadesinden sonraki ilk rakam dersi alan sinıfi, "ENM467" ifadesinden sonraki ilk parantez içi dersin verildiği öğretim zamanını(normal/ikinci), ikinci parantez içi dersi alan şubeyi, üçüncü parantez içi ise dersin tek oturuma mı yoksa iki oturuma mı sahip olduğunu göstermektedir. Birinci parantez içerisinde yer alabilecek değerler, "1", "2" ve "3" tür. "1", ifadesi normal öğretimi, "2" ifadesi ikinci öğretimi, "3" ifadesi ise her iki öğretim zamanını da içerdiğini göstermektedir. İkinci parantez içerisinde yer alabilecek değerler, "1", "2" ve "3" tür. "1", ifadesi, dersi "1. şubenin" aldığını, "2" ifadesi dersi " 2 . şubenin" aldığını, "3" ifadesi ise dersi her iki şubenin de aldığını göstermektedir. Son olarak üçüncü parantezin içi ise dersin kaç oturuma sahip olduğunu ifade etmektedir. Parantez içerisindeki ifadenin " 1 " olması dersin tek bir oturuma sahip olduğunu, "2" olması dersin iki oturuma sahip olduğunu göstermektedir.

\section{TELAFİ DERSİ ÇİZELGELEME PROBLEMI (TDÇP) VE MATEMATIKSEL MODELI (MAKEUP COURSE TIMETABLING PROBLEM (MCTP) AND MATHEMATICAL MODEL)}

TDÇP yapılamayan dersin, mevcut ders programı içerisinde herhangi bir öğretim elemanı ve şube çakışmasına izin vermeksizin uygun zaman dilimlerinde çizelgelenmesi gerekmektedir. Bu durum birçok kısıdı da beraberinde getirmektedir. $\mathrm{Bu}$ çalışmada TDÇP için ele alınan kısıtlar, ÜDÇP'de olduğu gibi sıkı ve esnek kısıtlar olmak üzere ikiye ayrılmıştır. TDÇP için bu çalışmada ele alınan sıkı kisitlar Tablo 4'de, esnek kisitlar Tablo 5'de gösterilmiştir.
Tablo 4. TDÇP kapsamında ele alınan sıkı kısıtlar (Hard constraints discussed under MCTP)

- Akademik takvim kapsamında sekizinci hafta vize haftası olarak belirlenmiş̧ir. Bu hafta içerisinde herhangi bir telafi dersinin yapilmasına izin verilmemektedir.

- Telafi dersleri mevcut ders programı koruncak şekilde uygun hafta, gün, saat ve dersliklere atanmalıdır.

- Bir telafí dersi aynı hafta, gün ve saat içerisinde yalnızca bir derslikte yapılabilir.

- Bir şubeye aynı hafta, gün ve saat içerisinde yalnız bir telafi dersi atanabilir.

- Bir öğretim elemanı aynı hafta, gün ve saat içerisinde tek bir şubeye ve tek bir dersliğe atanabilir.

- Bir günde telafi dersine ait en fazla üç kredi yapılabilir ve eğitim yalnızca hafta içi yapılmaktadır.

- Zorunlu derslerin seçmeli derslerle çakışmasına izin verilmemektedir.

Tablo 5. TDÇP kapsamında ele alınan esnek kısıtlar (Soft constraints discussed under MCTP)

- Derslik kapasitesinin aşılmaması istenmektedir.

- Telafi derslerine ait kredilerin aynı hafta ve gün içerisinde, aynı dersliklerde, ardışık saatlerde yapılması istenmektedir.

- İlgili bölümde dersler en az iki krediye sahiptir ve aynı hafta ve gün içerisinde ilgili derse ait en az iki kredinin çizelgelenmesi istenmektedir.

- Telafi dersine ait tüm kredilerin belirlenen sıkı kısitlardan dolayı çizelgelenmesi mümkün olmayabilir. Çizelgede olabildiğince telafi dersine ait tüm kredilerin yapılması amaçlanmaktadır. Örneğin zorunlu kalınırsa 3 kredilik bir dersin 2 saatlik blok şeklinde işlenmesine müsaade edilmektedir.

Telafi derslerinin çizelgelenmesi için kısıt ihlallerinin minimize edilmeye çalışıldığı yeni bir matematiksel model geliştirilmiştir. Modele ilişkin indis, küme, parametre ve kısıtlar aşağıda verilmiştir.

Telafi derslerinin çizelgelenmesinde kullanılan indisler aşağıdaki gibidir.

$$
\begin{array}{lll}
\mathrm{h}=\text { Hafta indisi } & \mathrm{h} \in \mathrm{H}=\left\{1,2, . ., \mathrm{h}_{\text {son }}\right\} \\
\mathrm{i}=\text { Gün indisi } & \mathrm{i} \in \mathrm{I}=\left\{1,2, . ., \mathrm{i}_{\text {son }}\right\} \\
\mathrm{j}=\text { Zamanindisi } & \mathrm{j} \in \mathrm{J}=\left\{1,2, . ., \mathrm{j}_{\text {son }}\right\} \\
\mathrm{m}=\text { Telafi ders indisi } & \mathrm{m}=\mathrm{p} \in \mathrm{M}=\left\{1,2, . ., \mathrm{m}_{\text {son }}\right\} \\
\mathrm{n}=\text { Derslik indisi } & \mathrm{n} \in \mathrm{N}=\left\{1,2, . ., \mathrm{n}_{\text {son }}\right\}
\end{array}
$$

Telafi derslerinin çizelgelenmesinde kullanılan kümeler aşağıdaki gibidir.

$$
\begin{aligned}
& \mathrm{Z}=\text { İki ve üç krediye sahip m dersleri } \\
& \mathrm{R}=\text { Üç ve beş krediye sahip m dersleri } \\
& \mathrm{L}=\text { Dört ve beş krediye sahip m dersleri } \\
& \mathrm{K}_{\mathrm{m}}=\mathrm{m} \text {. telafi dersinin aynı anda } \\
& \text { çizelgelenemeyeceği telafi dersleri } \\
& \mathrm{S}_{\mathrm{m}}=\mathrm{m} \text {. telafi dersinin yapılamayacağı günler } \\
& \mathrm{V}_{\mathrm{m}}=\mathrm{m} \text {. telafi dersinin yapılamayacağ } 1 \text { saatler } \\
& \mathrm{Y}=\text { Tüm telafi derslerinin yapılamayacağ } \\
& \text { saatler } \\
& \mathrm{O}=\text { Tüm telafi derslerinin yapilamayacağı } \\
& \text { günler } \\
& \mathrm{C}=\text { Tüm telafi derslerinin yapılamayacağ } \\
& \text { saatler } \\
& \mathrm{F}=\text { Tüm telafi derslerinin yapılamayacağ }
\end{aligned}
$$


$\mathrm{T}_{\mathrm{m}}=\mathrm{m}$. telafi dersinin yapılamayacağ $1 \quad \mathrm{iki}_{\mathrm{h}, \mathrm{i}, \mathrm{j}, \mathrm{m}, \mathrm{n}}$ haftalar

$\mathrm{U}=$ atıl $\mathrm{t}$ zamanlarının kümesi

$\mathrm{P}=$ atama yapılacak zamanların kümesi

Telafi derslerinin çizelgelenmesinde kullanılan parametreler aşağıdaki gibidir.

$$
\begin{array}{ll}
\mathrm{v}_{\mathrm{m}} & =\mathrm{m} \text { telafi dersine ait kredi sayısı } \\
\mathrm{d}_{\mathrm{m}} & =\mathrm{m} \text { telafi dersini alan öğrenci sayısı } \\
\mathrm{r}_{\mathrm{n}}= & \mathrm{n} \text { dersliğinin kapasitesi }
\end{array}
$$

Telafi derslerinin çizelgelenmesinde kullanılan değişkenler aşağıdaki gibidir.

$\begin{aligned} \mathrm{x}_{\mathrm{h}, \mathrm{i}, \mathrm{j}, \mathrm{m}, \mathrm{n}}= & 1, \mathrm{~m} . \text { ders, h. hafta, i. gün, j. } \\ & \text { saatte, n. derslikte yapılırsa } \\ & \text { 0, diğer durumda } \\ \mathrm{y}_{\mathrm{h}, \mathrm{i}, \mathrm{m}, \mathrm{n}}= & \text { 1, m. ders, h. hafta, i. gün, n. } \\ & \text { derslikte yapılırsa } \\ & \text { 0, diğer durumda } \\ = & 1, \text { m. ders, h. hafta yapılırsa } \\ & 0, \text { diğer durumda }\end{aligned}$

= h. hafta, i. gün, j. saatte, n derslikte $m$. telafi dersine ait ardışı iki saatte çizelgelenemeyen kredi sayısı

üçh,i,j,m,n $=$ h. hafta, i. gün, j. saatte, n. derslikte $m$. telafi dersine ait ardışı üç saatte çizelgelenemeyen kredi sayısı

$\mathrm{kap}_{\mathrm{h}, \mathrm{i}, \mathrm{j}, \mathrm{m}, \mathrm{n}}=\mathrm{h}$. hafta, i. gün, $\mathrm{j}$. saatte m. telafi dersinden kaynaklı n. dersliğin kapasitesini aşan öğrenci sayısı

$\operatorname{taban}_{\mathrm{h}, \mathrm{i}, \mathrm{m}, \mathrm{n}}=\mathrm{h}$. hafta, i. gün, $\mathrm{n}$ derslikte $\mathrm{m}$. telafi dersine ait iki krediden aşağı yapılan kredi sayısı

$\mathrm{kr}_{\mathrm{h}, \mathrm{i}, \mathrm{m}, \mathrm{n}}=\mathrm{h}$. hafta, i. gün, $\mathrm{n}$ derslikte, $\mathrm{m}$. telafi dersine ait yapilamayan kredi sayısı

$\mathrm{azl}_{\mathrm{m}} \quad=\mathrm{m}$. telafi dersine ait yapilamayan kredi sayısı

kredisagla $_{\mathrm{m}}=\mathrm{m}$. telafi dersinin fazladan atandığ 1 hafta sayısı

fazlahafta $_{\mathrm{m}}=\mathrm{m}$. telafi dersinin fazladan atand $\breve{g ̆}_{1}$ hafta, gün ve derslik sayısı

Telafi derslerinin çizelgelenmesinde kullanılan kısıtlar ve amaç fonksiyonu aşağıdaki gibidir.

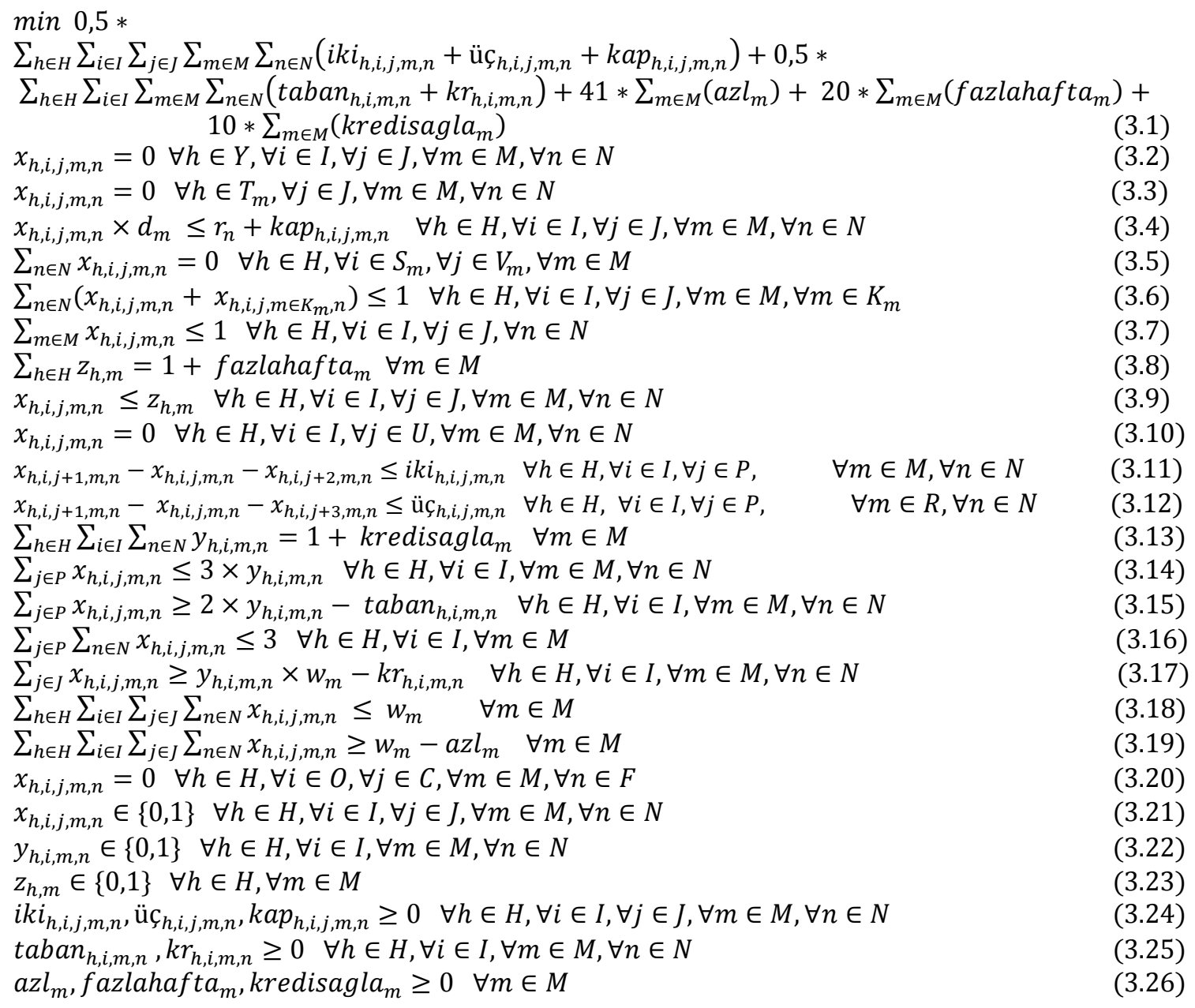


Modeldeki amaç fonksiyonu (3.1), uygun telafi ders programı oluştururken kısıt ihlallerini minimize etmeye çalışmaktadır. Kısıt kümesi (3.2), telafi derslerinin yapılamayacağı haftalarda çizelgelenmelerini engellemektedir. Kısıt kümesi (3.3), m'inci telafi dersinin çizelgelenemeyeceği haftalara atanması engellemektedir. Kısıt kümesi (3.4) dersliklere kapasitesinden fazla öğrenci atanmasını engellerken, kisıt kümesi (3.5), her bir telafi dersinin yapılamayacağı gün ve saatleri belirtir. Kısıt kümesi (3.6), telafi derslerinin kendi aralarında çakışmasını engellemektedir. Burada telafi dersinin, bu dersi alan şubelerin dersleriyle ve bu dersi veren öğretim elemanın dersleriyle çakışmasının önüne geçilmesi amaçlanmıştır. Seçmeli derslerin birbirleriyle çakışmaları dikkate alınmamıştır. Kısıt kümesi (3.7), ise bir dersliğe birden fazla dersin atanmasını engeller. Kısıt kümesi (3.8), bir telafi dersinin tek bir hafta içerisinde yapılmasını esnek bir kısıttır. Kısıt kümesi (3.9) ise kısıt kümesi (3.8) 'e bağlı olarak telafi derslerinin yalnızca atanmış olduğu haftalarda çizelgelenmesini sağlayan sikı bir kısıttır. K1sıt kümesi (3.10), atıl zamanlara ders atanmasını engeller. Kısıt kümesi (3.11) ve (3.12), iki ve üç krediye sahip derslerin ardış1k zaman dilimlerinde ve aynı dersliklerde yapılmasını, kısıt kümesi (3.13), telafi derslerinin tek bir hafta, gün ve derslik içerisinde çizelgelenmesini sağlayan esnek kısıtlardır. Kısıt kümesi (3.14), aynı gün ve derslikte bir telafi dersine ait en fazla üç kredinin yapılmasını sağlar. Kısıt kümesi (3.15), aynı gün ve derslikte bir telafi dersine ait en az iki kredinin yapılmasını sağlayan esnek bir kısıttır. Kısıt kümesi (3.16), aynı gün içerisinde bir derse ait en fazla üç kredinin çizelgelenebileceğini göstermektedir. Kısıt kümesi (3.17), bir derse ait kredilerin aynı hafta, gün ve derslikte yapılmasını sağlamaktadır. Kısıt kümesi (3.18), telafi dersinin sahip olduğu kredi sayısından fazla kredi atanmasını engellemektedir. Kısıt kümesi (3.19), telafi dersine ait tüm kredilerin atanmasını sağlayan esnek bir kısıttır. Kısıt kümesi (3.20), telafi derslerinin mevcut çizelgedeki dolu zaman boşluklarına atanmasını engelleyen sıkı bir kısıttır.
Kisit kümesi (3.21-3.22-3.23-3.24-3.25 ve 3.26), değişkenlere ait zaman kısıtlarıdır. Telafi Dersi Çizelgeleme Modeli 'nin etkinliğini ölçmek için çeşitli telafi senaryoları hazırlanmıştır. Bu senaryolar ikinci bölümde elde edilen lisans ders programından hareketle oluşturulmuştur. Senaryolara ilişkin bilgiler ve uygulama sonuçları bölüm 4'de verilmiştir.

\section{UYGULAMA ÇALIŞMASI (CASE STUDY)}

TDÇP, akademik kurumların her eğitim döneminde karşılaşabilecekleri bir problemdir. Probleme ilişkin özellikler giriş kısmında tartışılmıştı. Çalışmanın bu bölümünde giriş kısmında belirtilmiş olan olaylara benzer durumlar için 18 ayrı senaryo geliştirilmiş ve önerilen model, bu senaryolar üzerinde test edilmiştir. Telafi dersi çizelgeleme problemi için geliştirilmiş olan modeller, $8 \mathrm{~Gb}$ Ram ve $2.4 \mathrm{Ghz}$ işlemcili bilgisayarda IBM ILOG CPLEX Optimization Studio 12.6.0.0 optimizasyon programı yardımıyla çözülmüştür. Senaryo1, Senaryo2 ve Senaryo3'ün çözümüne ait istatistiksel bilgiler Tablo 7'de, geri kalan 15 senaryoya ilişkin istatistikler ise Tablo 9'da belirtilmiştir.

Senaryo 1: Öğretim elemanları, dönem başında akademik görevli olmaları veya mazeretleri sebebiyle belirtilen tarihlerde ders yapamayacaklarını bölüm başkanlığına bildirmişlerdir. Yapılamayan derslerin ileriki bir tarihte yapılması gerekmektedir. Yapılamayan derslere ilişkin bilgiler Tablo 6'da verilmiştir.

Senaryo 2: Bölümde düzenlenen sempozyum nedeniyle 4. haftada, pazartesi günü dersler yapılamayacaktır. $\mathrm{Bu}$ derslerin ileriki tarihlerde yapılması gerekmektedir.

Senaryo 3: Bölüm, 6. Hafta da ikinci sınıflara yönelik teknik gezi düzenlemeyi planlamıştır. Gezinin yapılacağı günleri Perşembe ve Cuma günleri olarak belirlemişlerdir. Gezi nedeniyle bugünlerde dersler yapılamayacaktır. $\mathrm{Bu}$ derslerin ileriki bir tarihte yapılması gerekmektedir.

Tablo 6. Senaryo-1'e ilişkin bilgiler (Information related to Scenario-1)

\begin{tabular}{|c|c|c|c|}
\hline $\begin{array}{l}\text { Dersin } \\
\text { Kodu }\end{array}$ & Dersin Adı & Dersi Alan Şube & $\begin{array}{l}\text { Dersin yapılmadığı } \\
\text { hafta/gün/saat/kredi }\end{array}$ \\
\hline ENM106 & Endüstri Mühendisliğine Giriş & Birinci Sınıf(1)Normal Öğretim(1) Birinci Şube(1) & 4/Çarşamba./08:30-11:20/3 \\
\hline ENM202 & Yöneylem Araştırması 1 & İkinci Sınıf(2) Birinci Öğretim(1) İkinci Şube(2) & 7/Salı/14:30-16:20/2 \\
\hline ENM224 & İmal Usulleri & İkinci Sınıf(2) Birinci Öğretim(1) Birinci Şube(1) & 5/Salı/08:30-11:20/3 \\
\hline ENM208 & Mühendislik İstatistiği & İkinci Sınıf(2) İkinci Öğretim(2) Birinci Şube(1) & 8/Perşembe/08:30-11:20/3 \\
\hline ENM312 & $\begin{array}{l}\text { Üretim Planlama ve Stok } \\
\text { Kontrol }\end{array}$ & Üçüncü Sınıf(3) Birinci Öğretim(1) İkinci Şube(2) & 9/Pazartesi/13:30-15:20/2 \\
\hline ENM306 & Yöneylem Araştırması-3 & Üçüncü Sınıf(3)Birinci Öğretim(1) İkinci Şube(2) & 3/Perşembe/08:30-11:20/3 \\
\hline ENM404 & Yönetim Bilgi Sistemleri & $\begin{array}{l}\text { Dördüncü Sınıf(4) Birinci Öğretim(1) İkinci } \\
\text { Şube(2) }\end{array}$ & 5/Perşembe/15:30-18:20/3 \\
\hline ENM455 & $\begin{array}{l}\text { Üretim Dağıtım Sistemleri } \\
\text { Planlaması }\end{array}$ & Dördüncü Sınıf(4) Tüm Şubeler & 7/Sal1/08:30-11:20/3 \\
\hline ENM471 & İş Sağllğı ve Güvenliği & Dördüncü Sınıf(4) Tüm Şubeler & 2/Çarşamba/16:30-19:20/3 \\
\hline M226 & Mühendislik Mekaniği & İkinci Sınıf(2) Birinci Öğretim(1) Tüm Şubeler & 3/Çarşamba/08:30-11:20/3 \\
\hline
\end{tabular}


Tablo 7. Senaryo1, Senaryo2 ve Senaryo3 ün çözümüne ilişkin bilgiler (Information related to solution of Scenario1, Scenario2 and Scenario3)

\begin{tabular}{|c|c|c|c|c|c|c|c|c|c|}
\hline Senaryo & $\begin{array}{l}\text { Ders } \\
\text { Sayısı }\end{array}$ & $\begin{array}{l}\text { Kredi } \\
\text { Sayısı }\end{array}$ & $\begin{array}{l}\text { Değişken } \\
\text { Sayısı }\end{array}$ & $\begin{array}{l}\text { Kisıt } \\
\text { Sayısı }\end{array}$ & $\begin{array}{l}\text { Yapılamayan } \\
\text { Kredi Sayısı }\end{array}$ & $\begin{array}{l}\text { Çözüm } \\
\text { Zamanı }\end{array}$ & $\begin{array}{l}\text { Amaç } \\
\text { Fonksiyonu }\end{array}$ & $\begin{array}{l}\text { Çözüm } \\
\text { Türü }\end{array}$ & Gap \\
\hline Senaryo1 & 10 & 28 & 354181 & 416335 & 3 & $\begin{array}{l}12 \text { saniye } 65 \\
\text { sanise }\end{array}$ & 125,5 & Optimal & $\% 0$ \\
\hline Senaryo2 & 16 & 42 & 566689 & 640229 & 0 & $\begin{array}{l}23 \text { saniye } 4 \\
\text { sanise }\end{array}$ & 0 & Optimal & $\% 0$ \\
\hline Senaryo3 & 7 & 17 & 247927 & 281973 & 0 & $\begin{array}{l}9 \text { saniye } 3 \\
\text { sanise }\end{array}$ & 0 & Optimal & $\% 0$ \\
\hline
\end{tabular}

Tablo 8. Rassal oluşturulmuş telafi dersi senaryoları (Random created makeup course scenarios)

\begin{tabular}{|l|l|l|}
\hline Senaryo & $\begin{array}{l}\text { Ders } \\
\text { Sayisı }\end{array}$ & Yaplamayan Dersler ve Haftalar(ders, hafta) \\
\hline Senaryo5_1 & 5 & $(48,9)-(5,11)-(70,4)-(78,7)-(40,5)$ \\
\hline Senaryo5_2 & 5 & $(12,1)-(42,11)-(74,1)-(19,7)-(69,5)$ \\
\hline Senaryo5_3 & 5 & $(24,13)-(55,13)-(68,11)-(27,11)-(67,3)$ \\
\hline Senaryo5_4 & 5 & $(77,12)-(59,11)-(76,1)-(47,12)-(66,9)$ \\
\hline Senary05_5 & 5 & $(58,1)-(6,3)-(44,1)-(73,10)-(55,2)$ \\
\hline Senaryo10_1 & 10 & $(7,3)-(46,4)-(23,2)-(69,7)-(1,1)-(31,9)-(30,13)-(11,10)-(3,2)-(70,1)$ \\
\hline Senaryo10_2 & 10 & $(25,9)-(51,2)-(36,9)-(31,3)-(14,1)-(58,12)-(17,7)-(24,4)-(61,10)-(78,7)$ \\
\hline Senaryo10_3 & 10 & $(18,3)-(71,5)-(55,7)-(73,3)-(11,4)-(47,9)-(2,6)-(68,11)-(58,10)-(31,11)$ \\
\hline Senaryo10_4 & 10 & $(64,9)-(61,5)-(68,2)-(69,1)-(51,2)-(57,11)-(66,7)-(37,10)-(3,9)-(49,11)$ \\
\hline Senaryo10_5 & 10 & $(22,11)-(71,2)-(29,1)-(26,11)-(41,10)-(6,11)-(56,12)-(14,1)-(4,4)-(18,13)$ \\
\hline Senaryo15_1 & 15 & $(34,1)-(67,2)-(53,1)-(20,12)-(11,10)-(48,10)-(28,11)-(17,7)-(13,7)-(1,6)-(78,9)-(37,13)-(75,3)-(15,2)-(38,9)$ \\
\hline Senaryo15_2 & 15 & $(42,3)-(57,4)-(18,1)-(16,9)-(29,13)-(17,12)-(12,4)-(40,4)-(65,5)-(75,7)-(21,13)-(4,3)-(51,10)-(9,1)-(23,6)$ \\
\hline Senaryo15_3 & 15 & $(66,6)-(2,10)-(41,13)-(39,13)-(67,9)-(5,11)-(55,9)-(73,5)-(14,10)-(4,12)-(58,1)-(45,4)-(7,9)-(74,13)-(10,1)$ \\
\hline Senaryo15_4 & 15 & $(55,3)-(59,10)-(66,11)-(78,9)-(49,7)-(21,3)-(3,13)-(32,5)-(63,9)-(9,10)-(62,4)-(17,7)-(69,4)-(73,2)-(38,13)$ \\
\hline Senaryo15_5 & 15 & $(16,7)-(28,10)-(33,4)-(22,4)-(69,5)-(54,3)-(66,4)-(64,6)-(18,2)-(74,4)-(34,2)-(30,9)-(19,6)-(70,13)-(36,3)$ \\
\hline
\end{tabular}

Üç telafi senaryosunda, üç farklı durum ele alınmıştır. Birinci senaryoda, farklı sinıf ve şubelerin yapılamayan derslerinin aynı anda düşünüldüğü karma bir TDÇP ele alınmıştır. İkinci senaryoda gün bazında yapılamayan derslere ait TDÇP ele alınmıştır. Üçüncü senaryoda yalnızca bir şubeye ait gün bazında yapılamayan dersler için telafi dersi çizelgeleme problemi ele alınmıştır. Çalışma kapsamında ele alınan problemlerin boyutuna ve çözümüne ilişkin bilgiler Tablo 7'de verilmiştir. Çıktılar, her bir problem için kabul edilebilir bir çözüm zamanı içerisinde uygun çizelgelerin elde edildiği göstermiştir. Tablo 7' deki amaç fonksiyon değerleri, istenilen amaçlara ne ölçüde ulaşıldığının bir göstergesidir. Hem lisans ders programı problemi hem de diğer senaryo problemleri için amaç minimizasyonudur ve amaç fonksiyon değerinin " 0 " olması arzu edilmektedir. Tablo 7'deki değerlere bakıldığında üç senaryo içinde optimal çözümün bulunduğu ifade edilmiştir. Tablo 15, Tablo 16 ve Tablo 17 'de, sirasılyla senaryo 1, senaryo 2 ve senaryo 3'e ait TDÇP için elde edilen sonuçlar gösterilmiştir. Tablolarda yapılamayan telafi derslerine ilişkin özellikler ile derslerin yapılacağı hafta, gün, saat ve dersliğe ait bilgileri yer almaktadır. Örneğin, senaryo 1 için Tablo 15'de birinci satırda "hafta3-Sal1-16:3017:20-4-3-3-ENM471-*Iș Sağlığ 1 ve Güvenliğidoc.dr.metindagdeviren-D408" ifadesi yer almaktadır. Burada telafi derslerinin atanmasına ilişkin bilgiler "" ile ayrılmıştır ve ilgili satırda toplamda 11 adet bilgi bulunmaktadır. İlk dört bilgide telafi dersinin hangi hafta, gün ve saat dilimleri arasında yapılacağı yer almaktadır. Sonraki üç bilgi dersin ait olduğu şubeye ilişkin bilgilerdir. İlk rakam dersin ait olduğu sınıfi (birinci (1), ikinci (2), üçüncü (3) veya dördüncü (4) sınıf), ikinci rakam o sınıfa ait öğretim zamanını (normal öğretim (1), ikinci öğretim (2) ve hem normal hem ikinci öğretime verilen ders (3)) ve üçüncü rakam da ilgili şubeyi (birinci şube (1), ikinci şube (2) ya da her iki şube (2)) ifade etmektedir. Son üç bilgi de ise yapılacak telafi dersinin ve dersi verecek öğretim elemanının adı ile dersin yapılacağ bilgiler yer almaktadır. $\mathrm{Bu}$ bilgiler doğrultusunda Tablo 15'de birinci satırda, 4. Sınıfta normal öğretim ve ikinci öğretimin tüm şubelerinin almış olabileceği İş Sağlığı ve Güvenliği Dersi' nin 3. Hafta Salı günü, 16:30-17:20 saatleri arasında telafi edileceği anlaşılmaktadır. Yukarıdaki senaryolar dışında 
Tablo 9. Rassal telafi dersi senaryolarının çözümüne ilişkin bilgiler (Information related to solution of random makeup course scenarios)

\begin{tabular}{|c|c|c|c|c|c|c|c|c|c|}
\hline Senaryo & $\begin{array}{c}\text { Ders } \\
\text { Sayisı }\end{array}$ & $\begin{array}{l}\text { Kredi } \\
\text { SayısI }\end{array}$ & $\begin{array}{c}\text { Değişken } \\
\text { Sayısı }\end{array}$ & $\begin{array}{c}\text { Kisıt } \\
\text { SayisI }\end{array}$ & $\begin{array}{c}\text { Yapılamayan } \\
\text { Kredi Sayısı }\end{array}$ & $\begin{array}{l}\text { Çözüm } \\
\text { Zamanı }\end{array}$ & $\begin{array}{c}\text { Amaç } \\
\text { Fonksiyonu }\end{array}$ & $\begin{array}{l}\text { Çözüm } \\
\text { Türü }\end{array}$ & Gap \\
\hline Senaryo5_1 & 5 & 15 & 177091 & 219675 & 0 & $\begin{array}{l}7 \text { saniye } 63 \\
\text { sanise }\end{array}$ & 0 & Optimal & $\% 0$ \\
\hline Senaryo5_2 & 5 & 16 & 177091 & 206989 & 0 & $\begin{array}{l}36 \text { saniye } 51 \\
\text { sanise }\end{array}$ & 2 & Optimal & $\% 0$ \\
\hline Senaryo5_3 & 5 & 13 & 177091 & 214740 & 13 & $\begin{array}{l}7 \text { saniye } 25 \\
\text { sanise }\end{array}$ & 0 & Optimal & $\% 0$ \\
\hline Senaryo5_4 & 5 & 15 & 177091 & 227910 & 3 & $\begin{array}{l}7 \text { saniye } 40 \\
\text { sanise }\end{array}$ & 125,5 & Optimal & $\% 0$ \\
\hline Senaryo5_5 & 5 & 15 & 177091 & 208540 & 0 & $\begin{array}{l}9 \text { saniye } 8 \\
\text { sanise }\end{array}$ & 0 & Optimal & $\% 0$ \\
\hline Senaryo10_1 & 10 & 33 & 354181 & 402962 & 0 & $\begin{array}{l}16 \text { dakika } 33 \\
\text { saniye }\end{array}$ & 6 & Optimal & $\% 0$ \\
\hline Senaryo10_2 & 10 & 28 & 354181 & 422765 & 3 & $\begin{array}{l}9 \text { saniye } 76 \\
\text { sanise }\end{array}$ & 125,5 & Optimal & $\% 0$ \\
\hline Senaryo10_3 & 10 & 31 & 354181 & 415528 & 0 & 1 saat & 37 & Feasible & $\% 5,86$ \\
\hline Senaryo10_4 & 10 & 31 & 354181 & 429034 & 3 & 1 saat & 127,5 & Optimal & $\% 0$ \\
\hline Senaryo10_5 & 10 & 30 & 354181 & 414723 & 0 & 1 saat & 37 & Feasible & $\% 7,21$ \\
\hline Senaryo15_1 & 15 & 49 & 531271 & 637111 & 0 & 1 saat & 8 & Feasible & $\% 66,67$ \\
\hline Senaryo15_2 & 15 & 49 & 531271 & 640671 & 0 & 1 saat & 8 & Feasible & $\% 66,67$ \\
\hline Senaryo15_3 & 15 & 49 & 531271 & 632096 & 0 & 1 saat & 8 & Feasible & $\% 66,67$ \\
\hline Senaryo15_4 & 15 & 48 & 531271 & 641947 & 6 & 1 saat & 257 & Feasible & $\% 1,33$ \\
\hline Senaryo15_5 & 15 & 47 & 531271 & 630933 & 0 & 1 saat & 4 & Feasible & $\% 37,50$ \\
\hline
\end{tabular}

modelin performansını test etmek için yapılamayacak olan derslerin ve bu derslerin yapılamayacağ haftaların rassal bir şekilde belirlendiği 15 farklı rassal senaryo oluşturulmuştur. Senaryolarda bilgisayar derslerinin, bilgisayar laboratuvarında yapılma zorunluluğu ve seçmeli derslerin birbiriyle çakışma durumu dikkate alınmamıștır. Senaryolara ilişkin bilgiler Tablo 8'de belirtilmiştir. Geliştirilen senaryolar bir saatlik bir zaman dilimi için koşturulmuş ve elde edilen sonuçlar Tablo 9'da verilmiştir. Ders sayısının beș olduğu tüm durumlar için optimal sonuç çok kısa sürelerde elde edilmiştir. Yapılaman ders sayısı 10 olduğunda ise senaryoya göre çözüm zamanı değişmektedir. Senaryo10_1 ve Senaryo10_2 ve Senaryo10_4' de bir saatlik çözüm zamanı içerisinde optimal çözüm elde edilirken, Senaryo10_3 ve Senaryo10_5 de bir saatlik zaman dilimi içerisinde uygun çözümler elde edilmiştir. Yapılamayan ders sayısı 15 olduğunda ise bir saatlik çözüm içerisinde optimal çözüm bulunamamış yalnızca uygun çözümler elde edilmiştir. Bu durumun temel nedenlerinden biri 15 adet telafi dersinin yapılması gerektiği senaryolarda kısıt sayısının çok olmasından kaynaklanmaktadır.

\section{SONUÇLAR (CONCLUSIONS)}

$\mathrm{Bu}$ çalışmada, literatürde az ilgilenilmiş olan telafi dersi çizelgeleme problemi farklı bir açıdan ele alınmıştır. Telafi dersi çizelgeleme problemi yeniden tanımlanmış, problemin çözümü için yeni bir matematiksel model geliştirilmiş ve önerilen model Gazi Üniversitesi Endüstri Mühendisliği Bölümünde uygulanmıştır. Uygulama kapsamında ilk olarak ilgili bölüm için lisans dersleri çizelgelenmiş, daha sonra bu çizelgeden hareketle telafi ders senaryoları hazırlanmıştır. Hazırlanan senaryolar, telafi dersi çizelgeleme problemi için geliştirilmiş olan matematiksel model yardımıyla çözülmüştür. Modelin bazı senaryolarda çok kısa sürelerde optimal çözüme ulaştığ 1 bazı senaryolarda ise kabul edilebilir zaman içerisinde sadece uygun çözümler üretebildiği ve optimal çözüme ulaşamadığı görülmüștür. Bu durum, problemin çok sayıda değişken ve kısıda sahip olmasından kaynaklanmaktadır. Model içerisindeki parametrelerde (ders sayısı, derslik sayısı, zaman dilimi sayısı) meydana gelen artış, modelin çözüm zamanını ve etkinliğini olumsuz yönde etkileyen faktörlerdir. Gelecek çalışmalarda geliştirilmiş olan matematiksel modele, sezgisel yöntem, yapay zekâ ve doğru arama-budama stratejileri uygulayarak, büyük boyutlu problemler de kabul edilebilir zamanlar içinde çözümler alınabileceği düşünülmektedir.

Ayrıca önerilen modelin bazı modifikasyonların yapılmasıyla ders çizelgeleme problemleri dışında farklı alanlarda da uygulanabileceği düşünülmektedir. $\mathrm{Bu}$ alanlar; Çeşitli nedenlerden dolayı aksayan bir projenin teslim zamanı içerisinde yetiştirilmesi için kaynak ve ekipmanın mevcut şartlar altında yeniden çizelgelenmesi, fabrikalarda gelen ani siparişlerin, mevcut üretim programını bozmadan ya da en az şekilde bozacak şekilde, ilgili teknolojik kısttlar altında üretim programına dahil edilmesi, çeşitli nedenlerden dolayı ertelenen uçuşların mevcut uçuş programı içerisinde çizelgelenmesi, çeşitli durumlardan dolayı polislerin, uçuş mürettebatının, doktorların veya hemşirelerin nöbet ve görev 
çizelgelerinin, mevcut aylık ya da haftalık çizelge altında yeniden çizelgelenmesidir. Her bir uygulama alanı kendi ait özelliklere ve kısıtlara sahiptir. Bu nedenden dolayı modeli farklı alanlarda uygularken bir takım sorunlarla karşılaşılabilir. Değişken yapısında meydana gelen değişiklikler, yeni kısıtların eklenmesi ya da mevcut kısıtların çıkarılması bu sorunlardan bazılarıdır. Modelde yapılacak uygun değişikler ile bu sorunların giderileceği düşünülmektedir.

\section{KAYNAKLAR (REFERENCES)}

1. Internet: http://www.timeturk.com/kocaeli-ndeuniversite-tatil-edildi/haber-116480

2. İnternet:

http://www.universityworldnews.com/article.php ?story $=20150429122217633$

3. İnternet: https://bianet.org/bianet/egitim/162624ege-universitesi-nde-uc-gun-sonra-ders-basi

4. İnternet: http://www.milliyet.com.tr/5-6-8-9haziran-2015-okullar-tatil-gundem-2069336/

5. İnternet:

http://www.gemipersoneli.com/haberler/613/bang lades'e-yaklasan-dev-hortum-nedeniyle-limankentlerine-en-yuksek-duzeyde-alarm-verildi

6. Chen, R. M., ve Shih, H. F., "Solving University Course Timetabling Problems Using Constriction Particle Swarm Optimization with Local Search", Algorithms, Cilt 6, No 2, 227-244, 2013.

7. Al-Yakoob, S. M. ve Sherali, H. D., "Mathematical Models and Algorithms For A High School Timetabling Problem", Computers \& Operations Research, Cilt 61, 56-68, 2015.

8. Daskalaki, S., Birbas, T. ve Housos, E., "An Integer Programming Formulation For A Case Study In University Timetabling", European Journal of Operational Research, Cilt 153, No 1, 117-135, 2004.

9. Köçken, H. G., Özdemir, R., \& Ahlatcioğlu, M., "Üniversite Ders Zaman Çizelgeleme Problemi Için Ikili Tamsayılı Bir Model ve Bir Uygulama", Journal of the School of Business Administration, Istanbul University, Cilt 43, No 1, 28-54, 2014.

10. MirHassani, S. A., "A Computational Approach To Enhancing Course Timetabling with Integer Programming", Applied Mathematics and Computation, Cilt 175, No 1, 814-822, 2006

11. Santos, H. G., Uchoa, E., Ochi, L. S., \& Maculan, N., "Strong Bounds with Cut and Column Generation for Class-Teacher Timetabling", Annals of Operations Research, Cilt 194, No 1, 399-412, 2012.

12. Schimmelpfeng, K. and Helber, S. "Application of a real-world university-course timetabling model solved by integer programming". Or Spectrum, Cilt 29, No 4, 783-803, 2007.

13. Ismayilova, N. A., Sağir, M. and Gasimov, R. N., "A multiobjective faculty-course-time slot assignment problem with preferences", Mathematical and Computer Modelling, Cilt 46, No 7, 1017-1029, 2007.

14. Bakir, M. A. ve Aksop, C., "A 0-1 integer programming approach to a university timetabling problem", Hacettepe Journal of Mathematics and Statistics, Cilt 37, No 1, 2008.

15. Küçüksille, E. U. ve Tokmak, M., "Yapay Ar1 Kolonisi Algoritması Kullanarak Otomatik Ders Çizelgeleme", Journal of Natural \& Applied Sciences, Cilt 15, No 3, 2011.

16. Yiğit, T., "Meslek Liseleri Haftalık Ders Çizelgelerinin Genetik Algoritmalar Yardımıyla Oluşturulması", Gazi Üniversitesi Endüstriyel Sanatlar Eğitim Fakültesi Dergisi, Cilt 19, 2539, 2006.

17. Abramson, D., "Constructing School Timetables Using Simulated Annealing: Sequential and Parallel Algorithms", Management science, Cilt 37, No 1, 98-113, 1991.

18. Valouxis, C. ve Housos, E., "Constraint Programming Approach for School Timetabling”, Computers \& Operations Research, Cilt 30, No 10, 1555-1572, 2003.

19. Papoutsis, K., Valouxis, C., ve Housos, E. "A column generation approach for the timetabling problem of Greek high schools", Journal of the Operational Research Society, Cilt 54, No 3, 230-238, 2003.

20. Gunawan, A., Ng, K. M., ve Poh, K. L., "A Hybridized Lagrangian Relaxation And Simulated Annealing Method for the Course Timetabling Problem", Computers \& Operations Research, Cilt 39, No 12, 30743088, 2012.

21. Gerşil, M. ve Palamutçuoğlu, T., "Ders Çizelgeleme Probleminin Melez Genetik Algoritmalar İle Performans Analizi”, Niğde Üniversitesi İktisadi ve İdari Bilimler Fakültesi Dergisi, Cilt 6, No 1, 242, 2013.

22. Harjunkoski, I., ve Grossmann, I. E., "Decomposition Techniques For Multistage Scheduling Problems Using Mixed-Integer and Constraint Programming Methods", Computers \& Chemical Engineering, Cilt 26, No 11, 15331552, 2002.

23. Rudová, H., Müller, T., ve Murray, K., “Complex University Course Timetabling", Journal of Scheduling, Cilt 14, No 2, 187-207, 2011.

24. Mahiba, A. A. ve Durai, C. A. D., "Genetic Algorithm with Search Bank Strategies for University Course Timetabling Problem", Procedia Engineering, Cilt 38, 253-263, 2012.

25. Kohshori, M. S., M. S. Abadeh ve Sajedi, H., "A fuzzy genetic algorithm with local search for university course timetabling. Data Mining and Intelligent Information Technology Applications (ICMiA), 2011 3rd International Conference on, 250-254, 2011, IEEE. 
26. Rachmawati, L. ve Srinivasan, D., "A hybrid fuzzy evolutionary algorithm for a multiobjective resource allocation problem", Hybrid Intelligent Systems, 2005. HIS'05. Fifth International Conference on, 2005, IEEE.

27. Golabpour, A., Farahi, A., Beigi, H., Shirazi, H., and Kootiani, A., "A fuzzy solution based on Memetic algorithms for timetabling", MultiMedia and Information Technology, 2008. MMIT'08, International Conference on, 108-110, 2008, IEEE.

28. Pongcharoen, P., Promtet, W., Yenradee, P., ve Hicks, C., "Stochastic optimisation timetabling tool for university course scheduling", International Journal of Production Economics, Cilt 112, No 2, 903-918, 2008.

29. Asmuni, H., Burke, E. K., ve Garibaldi, J. M., "Fuzzy multiple heuristic ordering for course timetabling", Proceedings of the 5th United Kingdom workshop on computational intelligence (UKCI 2005), 2005, Citeseer.
30. Shiau, D. F., "A Hybrid Particle Swarm Optimization for A University Course Scheduling Problem with Flexible Preferences", Expert Systems with Applications, Cilt 38, No 1, 235248, 2011.

31. Shen, L. W., Asmuni, H., \& Weng, F. C., "A Modified Migrating Bird Optimization for University Course Timetabling Problem”, Jurnal Teknologi, Cilt 72, No 1, 2014.

32. Shimazaki, S., Kunio S., ve Tad Mat., "Iterative Optimization Techniques Based on Man-Machine Interaction for Timetabling Problems." Computational Intelligence and Applications (IWCIA), 2014 IEEE 7th International Workshop on, 2014, IEEE.

33. Chaudhry, N., Nayab, R., Bashir, S., Alvi, F., Taimoor, S, A, M., "Integrating Case-Based Reasoning and Tabu Search for University Makeup Class Scheduling", Journal of Applied Enviromental and Biological Sciences", Cilt 4, No 9S, 36-44, 2014. 
EKLER (Appendices)

Tablo 10. Bahar Yarıyılı Pazartesi Gününe Ait Ders Programı (Course Program of Spring Semester Monday Day)

\begin{tabular}{|c|c|c|c|c|c|c|c|c|}
\hline Pazartesi & 403 & 404 & 406 & 407 & 408 & 409 & 411 & 41 \\
\hline 08:30-09:20 & & ENM467(3)(3)(1) & & ENM202(2)(2)(2) & & & ENM361(3)(3)(1) & \\
\hline 09:30-10:20 & & ENM467(3)(3)(1) & & ENM202(2)(2)(2) & & & ENM361(3)(3)(1) & \\
\hline 10:30-11:20 & & ENM467(3)(3)(1) & & & & ENM224(2)(1)(1) & ENM361(3)(3)(1) & MM226(1)(3)(1 \\
\hline 11:30-12:20 & & & ENM369(3)(3)(1) & $5 S 472(F G)(3)(3)(1)$ & & ENM224(2)(1)(1) & & MM226(1)(3)(1 \\
\hline 12:30-13:20 & & & ENM369(3)(3)(1) & SS472(FG)(3)(3)(1) & & ENM224(2)(1)(1) & & MM226(1)(3)(1 \\
\hline 13:30-14:20 & & SS472(Tr)(3)(3)(1) & ENM369(3)(3)(1) & $5 S 472(\mathrm{FG})(3)(3)(1)$ & & ENM202(2)(1)(2) & ENM224(1)(2)(1) & \\
\hline $14: 30-15: 20$ & & SS472(TYY)(3)(3)(1) & & & ENM355(3)(3)(1) & ENM202(2)(1)(2) & ENM224(1)(2)(1) & \\
\hline $15: 30-16: 20$ & & SS472(TVY)(3)(3)(1) & & & ENM355(3)(3)(1) & & ENM224(1)(2)(1) & \\
\hline $16: 30-17: 20$ & & & & ENM466(3)(3)(1) & ENM355(3)(3)(1) & & ENM252(3)(3)(1) & \\
\hline $17: 30-18: 20$ & & & ENM312(1)(1)(2) & ENM466(3)(3)(1) & ENM312(2)(1)(2) & & ENM252(3)(3)(1) & ENM312(1)(2)(2 \\
\hline 18:30-19:20 & & & ENM312(1)(1)(2) & ENM466(3)(3)(1) & ENM312(2)(1)(2) & & & ENM312(1)(2)(2 \\
\hline
\end{tabular}

Tablo 11. Bahar Yarıyılı Salı Gününe Ait Ders Programı (Course Program of Spring Semester Tuesday Day)

\begin{tabular}{|c|c|c|c|c|c|c|c|c|}
\hline Salı & 403 & 404 & 406 & 407 & 408 & 409 & 411 & 41 \\
\hline 08:30-09:20 & & ENM456(3)(3)(1) & & & & ENM106(2)(1)(1) & & \\
\hline 09:30-10:20 & & ENM456(3)(3)(1) & & ENM208(2)(2)(1) & & ENM106(2)(1)(1) & ENM353(3)(3)(1) & \\
\hline 10:30-11:20 & ENF106(1)(2)(2) & ENM456(3)(3)(1) & & ENM208(2)(2)(1) & & ENM106(2)(1)(1) & ENM353(3)(3)(1) & \\
\hline $11: 30-12: 20$ & ENF106(1)(2)(2) & & & ENM208(2)(2)(1) & & ENM206(2)(1)(1) & ENM353(3)(3)(1) & ENM469(3)(3)(1 \\
\hline 12:30-13:20 & ENF106(2)(1)(2) & & & & & ENM206(2)(1)(1) & ENM208(1)(2)(1) & ENM469(3)(3)(1 \\
\hline 13:30-14:20 & ENF106(2)(1)(2) & & ENM322(1)(2)(1) & & & ENM206(2)(1)(1) & ENM208(1)(2)(1) & ENM469(3)(3)(1 \\
\hline 14:30-15:20 & & & ENM322(1)(2)(1) & & & ENM312(2)(2)(2) & ENM208(1)(2)(1) & ENM458(3)(3)(1 \\
\hline 15:30-16:20 & & & ENM322(1)(2)(1) & ENM253(3)(3)(1) & & ENM312(2)(2)(2) & & ENM458(3)(3)(1 \\
\hline 16:30-17:20 & & & ENM372(3)(3)(1) & ENM253(3)(3)(1) & & & & ENM458(3)(3)(1 \\
\hline $17: 30-18: 20$ & & ENM202(1)(2)(2) & ENM372(3)(3)(1) & & & ENM443/ENM444(3)(3)(2) & & \\
\hline $18: 30-19: 20$ & & ENM202(1)(2)(2) & ENM372(3)(3)(1) & & & ENM443/ENM444(3)(3)(2) & & \\
\hline
\end{tabular}

Tablo 12. Bahar Yarıyılı Çarşamba Gününe Ait Ders Programı (Course Program of Spring Semester Wendesday Day)

\begin{tabular}{|c|c|c|c|c|c|c|c|c|}
\hline Çarşamba & 403 & 404 & 406 & 407 & 408 & 409 & 411 & 41 \\
\hline 08:30-09:20 & & & ENM316(2)(2)(1) & ENM208(1)(1)(1) & & ENM306(1)(1)(1) & ENM106(1)(2)(1) & ENM471(3)(3)(1 \\
\hline $09: 30-10: 20$ & ENF106(1)(1)(2) & & ENM316(2)(2)(1) & ENM208(1)(1)(1) & & ENM306(1)(1)(1) & ENM106(1)(2)(1) & ENM471(3)(3)(1 \\
\hline 10:30-11:20 & ENF106(1)(1)(2) & & ENM316(2)(2)(1) & ENM208(1)(1)(1) & & ENM306(1)(1)(1) & ENM106(1)(2)(1) & ENM471(3)(3)(1 \\
\hline 11:30-12:20 & & & & SS472(SP)(3)(3)(1) & ENM344(3)(3)(2) & & & \\
\hline $12: 30-13: 20$ & & & & SS472(SP)(3)(3)(1) & ENM344(3)(3)(2) & ENM254(3)(3)(1) & & \\
\hline $13: 30-14: 20$ & & & ENM306(2)(2)(1) & SS472(SP)(3)(3)(1) & & ENM254(3)(3)(1) & & \\
\hline $14: 30-15: 20$ & & ENM463(3)(3)(1) & ENM306(2)(2)(1) & ENM306(2)(1)(1) & ENM322(1)(1)(1) & ENM306(1)(2)(1) & & MM226(2)(3)(1 \\
\hline $15: 30-16: 20$ & & ENM463(3)(3)(1) & ENM306(2)(2)(1) & ENM306(2)(1)(1) & ENM322(1)(1)(1) & ENM306(1)(2)(1) & & MM226(2)(3)(1 \\
\hline $16: 30-17: 20$ & & ENM463(3)(3)(1) & ENM455(3)(3)(1) & ENM306(2)(1)(1) & ENM322(1)(1)(1) & ENM306(1)(2)(1) & & MM226(2)(3)(1 \\
\hline $17: 30-18: 20$ & & & ENM455(3)(3)(1) & & ENM250(3)(3)(1) & ENM312(2)(1)(2) & & \\
\hline $18: 30-19: 20$ & & & ENM455(3)(3)(1) & & ENM250(3)(3)(1) & ENM312(2)(1)(2) & & \\
\hline
\end{tabular}

Tablo 13. Bahar Yarıyılı Perşembe Gününe Ait Ders Programı (Course Program of Spring Semester Thursday Day)

\begin{tabular}{|c|c|c|c|c|c|c|c|c|}
\hline Perşembe & 403 & 404 & 406 & 407 & 408 & 409 & 411 & 41 \\
\hline 08:30-09:20 & & & & ENM443/ENM444(3)(3)(2) & & & ENM370(3)(3)(1) & \\
\hline 09:30-10:20 & & & ENM224(1)(1)(1) & ENM443/ENM444(3)(3)(2) & & & ENM370(3)(3)(1) & \\
\hline 10:30-11:20 & & & ENM224(1)(1)(1) & ENM404(1)(1)(1) & ENM404(1)(2)(1) & & ENM370(3)(3)(1) & ENM406(2)(3)(1 \\
\hline $11: 30-12: 20$ & & & ENM224(1)(1)(1) & ENM404(1)(1)(1) & ENM404(1)(2)(1) & ENM316(2)(1)(1) & & ENM406(2)(3)(1) \\
\hline 12:30-13:20 & & & & ENM404(1)(1)(1) & ENM404(1)(2)(1) & ENM316(2)(1)(1) & ENM322(2)(2)(1) & \\
\hline 13:30-14:20 & & ENM404(2)(2)(1) & & ENM406(1)(3)(1) & ENM404(2)(1)(1) & ENM316(2)(1)(1) & ENM322(2)(2)(1) & ENM312(1)(1)(2 \\
\hline 14:30-15:20 & & ENM404(2)(2)(1) & ENM202(1)(1)(2) & ENM406(1)(3)(1) & ENM404(2)(1)(1) & & ENM322(2)(2)(1) & ENM312(1)(1)(2 \\
\hline 15:30-16:20 & $\operatorname{ENF106(2)(2)(2)~}$ & ENM404(2)(2)(1) & ENM202(1)(1)(2) & ENM206(2)(2)(1) & ENM404(2)(1)(1) & ENM312(2)(2)(2) & & \\
\hline $16: 30-17: 20$ & ENF106(2)(2)(2) & ENM476(3)(3)(1) & & ENM206(2)(2)(1) & ENM316(1)(2)(1) & ENM312(2)(2)(2) & ENM316(1)(1)(1) & ENM450(3)(3)(1 \\
\hline 17:30-18:20 & & ENM476(3)(3)(1) & & ENM206(2)(2)(1) & $\operatorname{ENM} 316(1)(2)(1)$ & & ENM316(1)(1)(1) & ENM450(3)(3)(1 \\
\hline 18:30-19:20 & & ENM476(3)(3)(1) & & & ENM316(1)(2)(1) & & ENM316(1)(1)(1) & ENM450(3)(3)(1 \\
\hline
\end{tabular}


Tablo 14. Bahar Yarıyılı Cuma Gününe Ait Ders Programı ( Course Program of Spring Semester Friday Day)

\begin{tabular}{|c|c|c|c|c|c|c|c|c|}
\hline Cuma & 403 & 404 & 406 & 407 & 408 & 409 & 411 & 41 \\
\hline 08:30-09:20 & & ENM344(3)(3)(2) & & & ENM459(3)(3)(1) & ENM106(1)(1)(1) & ENM202(2)(1)(2) & ENM202(1)(1)(2 \\
\hline 09:30-10:20 & $\operatorname{ENF106(2)(2)(2)}$ & ENM344(3)(3)(2) & ENM202(1)(2)(2) & & ENM459(3)(3)(1) & ENM106(1)(1)(1) & ENM202(2)(1)(2) & ENM202(1)(1)(2 \\
\hline 10:30-11:20 & ENF106(2)(2)(2) & & ENM202(1)(2)(2) & & ENM459(3)(3)(1) & ENM106(1)(1)(1) & ENM224(2)(2)(1) & ENM373(3)(3)(1 \\
\hline 11:30-12:20 & ENF106(1)(1)(2) & & ENM453(3)(3)(1) & ENM206(1)(3)(1) & & & ENM224(2)(2)(1) & ENM373(3)(3)(1 \\
\hline 12:30-13:20 & $\operatorname{ENF106(1)(1)(2)~}$ & & ENM453(3)(3)(1) & ENM206(1)(3)(1) & $\operatorname{SS472(PG)(3)(3)(1)}$ & & ENM224(2)(2)(1) & ENM373(3)(3)(1 \\
\hline 13:30-14:20 & & ENM322(2)(1)(1) & ENM453(3)(3)(1) & ENM206(1)(3)(1) & $5 S 472(\mathrm{PG})(3)(3)(1)$ & & & \\
\hline $14: 30-15: 20$ & & ENM322(2)(1)(1) & & & $\operatorname{SS472(PG)(3)(3)(1)}$ & ENM470(3)(3)(1) & ENM312(1)(2)(2) & \\
\hline $15: 30-16: 20$ & ENF106(1)(2)(2) & ENM322(2)(1)(1) & & & ENM106(2)(2)(1) & ENM470(3)(3)(1) & ENM312(1)(2)(2) & \\
\hline $16: 30-17: 20$ & ENF106(1)(2)(2) & & & & ENM106(2)(2)(1) & ENM470(3)(3)(1) & ENM208(2)(1)(1) & ENM451(3)(3)(1 \\
\hline 17:30-18:20 & ENF106(2)(1)(2) & & & & ENM106(2)(2)(1) & ENM202(2)(2)(2) & ENM208(2)(1)(1) & ENM451(3)(3)(1 \\
\hline 18:30-19:20 & ENF106(2)(1)(2) & & & & & ENM202(2)(2)(2) & ENM208(2)(1)(1) & ENM451(3)(3)(1 \\
\hline
\end{tabular}

Tablo 15: Senaryo-1 için telafi ders programı (Makeup Course Program for Scenario-1)

hafta3-Sal1-16:30-17:20-4-3-3-ENM471-*İs Sağlığ1 ve Güvenliği-doc.dr.metindagdeviren-D408 hafta3-Salı-17:30-18:20-4-3-3-ENM471-*İş Sağlı̆̆1 ve Güvenliği-doc.dr.metindagdeviren-D408 hafta3-Sal1-18:30-19:20-4-3-3-ENM471-*Işs Sağlı̆̆1 ve Güvenliği-doc.dr.metindagdeviren-D408 hafta4-Sal1-08:30-09:20-2-1-3-MM226-Mühendislik Mekaniği-ogr.gor.tuncapatay-D414 hafta4-Sal1-09:30-10:20-2-1-3-MM226-Mühendislik Mekaniği-ogr.gor.tuncapatay-D414 hafta4-Sal1-10:30-11:20-2-1-3-MM226-Mühendislik Mekaniği-ogr.gor.tuncapatay-D414 hafta5-Perşembe-08:30-09:20-1-1-1-ENM106-Endüstri Mühendisliğine Giriş-doc.dr.h.edizatmaca-D409 hafta5-Perşembe-09:30-10:20-1-1-1-ENM106-Endüstri Mühendisliğine Giriş-doc.dr.h.edizatmaca-D409 hafta5-Perşembe-10:30-11:20-1-1-1-ENM106-Endüstri Mühendisliğine Giriş-doc.dr.h.edizatmaca-D409 hafta6-Perşembe-16:30-17:20-2-1-1-ENM224-İmal Usulleri-doc.dr.adnanakkurt-D406 hafta6-Perşembe-17:30-18:20-2-1-1-ENM224-İmal Usulleri-doc.dr.adnanakkurt-D406 hafta6-Perşembe-18:30-19:20-2-1-1-ENM224-İmal Usulleri-doc.dr.adnanakkurt-D406 hafta7-Çarşamba-08:30-09:20-3-1-2-ENM306-Yöneylem Araştırması 3-prof.dr.bilaltoklu-D404 hafta7-Çarşamba-09:30-10:20-3-1-2-ENM306-Yöneylem Araștırması 3-prof.dr.bilaltoklu-D404 hafta7-Çarşamba-10:30-11:20-3-1-2-ENM306-Yöneylem Araştırması 3-prof.dr.bilaltoklu-D404 hafta9-Perşembe-12:30-13:20-2-1-2-ENM202-Yöneylem Araştırması 1-doc.dr.mehmetatak-D406 hafta9-Perşembe-13:30-14:20-2-1-2-ENM202-Yöneylem Araştırması 1-doc.dr.mehmetatak-D406 hafta9-Cuma-11:30-12:20-4-3-3-ENM455-Üretim Dağıtım Sistemleri Planlaması-yrd.doc.dr.muratarikanD409

hafta9-Cuma-12:30-13:20-4-3-3-ENM455-Üretim Dağıtım Sistemleri Planlamas1-yrd.doc.dr.muratarikanD409

hafta9-Cuma-13:30-14:20-4-3-3-ENM455-Üretim Dağıtım Sistemleri Planlamas1-yrd.doc.dr.muratarikanD409

hafta10-Çarşamba-17:30-18:20-3-1-2-ENM312-Üretim Planlama Ve Stok Kontrologr.gor.dr.hakancercioglu-D403

hafta10-Çarşamba-18:30-19:20-3-1-2-ENM312-Üretim Planlama Ve Stok Kontrol-

ogr.gor.dr.hakancercioglu-D403

hafta15-Cuma-13:30-14:20-2-2-1-ENM208-Mühendislik İstatistiği-doc.dr.ugurozcan-D414

hafta15-Cuma-14:30-15:20-2-2-1-ENM208-Mühendislik İstatistiği-doc.dr.ugurozcan-D414

hafta15-Cuma-15:30-16:20-2-2-1-ENM208-Mühendislik İstatistiği-doc.dr.ugurozcan-D414 
Tablo 16. Senaryo-2 için telafi ders programı (Makeup Course Program for Scenario-2)

hafta5-Pazartesi-08:30-09:20-4-3-3-ENM466-uluslararasi.finans-prof.dr.zulalgungor-D406

hafta5-Pazartesi-09:30-10:20-4-3-3-ENM466-uluslararasi.finans-prof.dr.zulalgungor-D406 hafta5-Pazartesi-10:30-11:20-4-3-3-ENM466-uluslararasi.finans-prof.dr.zulalgungor-D406 hafta5-Pazartesi-11:30-12:20-2-2-2-ENM202-yoneylem.arastirmasi.1-yrd.doc.dr.muratarikan-D411 hafta5-Pazartesi-12:30-13:20-2-2-2-ENM202-yoneylem.arastirmasi.1-yrd.doc.dr.muratarikan-D411 hafta5-Pazartesi-14:30-15:20-4-3-3-SS472(FG)-felsefeye.giris-prof.dr.kazimsarikavak-D406 hafta5-Pazartesi-15:30-16:20-4-3-3-SS472(FG)-felsefeye.giris-prof.dr.kazimsarikavak-D406 hafta5-Pazartesi-16:30-17:20-4-3-3-ENM476-malzeme.tasima.ve.depolama.sistemleriyrd.doc.dr.yesimkalender-D404

hafta5-Pazartesi-16:30-17:20-4-3-3-SS472(TTY)-turkiyenin.toplumsal.yapisi-doc.dr.aysecanatan-D409 hafta5-Pazartesi-16:30-17:20-4-3-3-SS472(FG)-felsefeye.giris-prof.dr.kazimsarikavak-D406 hafta5-Pazartesi-17:30-18:20-4-3-3-ENM476-malzeme.tasima.ve.depolama.sistemleriyrd.doc.dr.yesimkalender-D404

hafta5-Pazartesi-17:30-18:20-4-3-3-SS472(TTY)-turkiyenin.toplumsal.yapisi-doc.dr.aysecanatan-D409 hafta5-Pazartesi-18:30-19:20-4-3-3-ENM476-malzeme.tasima.ve.depolama.sistemleriyrd.doc.dr.yesimkalender-D404

hafta5-Pazartesi-18:30-19:20-4-3-3-SS472(TTY)-turkiyenin.toplumsal.yapisi-doc.dr.aysecanatan-D409 hafta5-Sal1-17:30-18:20-2-2-1-ENM202-yoneylem.arastirmasi.1-doc.dr.feyzanarikan -D414 hafta5-Sal1-18:30-19:20-2-2-1-ENM202-yoneylem.arastirmasi.1-doc.dr.feyzanarikan -D414 hafta5-Çarşamba-17:30-18:20-3-1-2-ENM312-uretim.planlama.ve.stok.kontrol-ogr.gor.dr.hakancerciogluD407

hafta5-Çarşamba-18:30-19:20-3-1-2-ENM312-uretim.planlama.ve.stok.kontrol-ogr.gor.dr.hakancerciogluD407

hafta5-Perşembe-08:30-09:20-3-3-3-ENM355-isletme.yonetimi-prof.dr.mustafakurt-D403

hafta5-Perşembe-08:30-09:20-3-3-3-ENM361-pazarlama-prof.dr.nurettinpariltili-D404 hafta5-Perşembe-09:30-10:20-3-3-3-ENM355-isletme.yonetimi-prof.dr.mustafakurt-D403

hafta5-Perşembe-09:30-10:20-3-3-3-ENM361-pazarlama-prof.dr.nurettinpariltili-D404 hafta5-Perşembe-10:30-11:20-3-3-3-ENM355-isletme.yonetimi-prof.dr.mustafakurt-D403 hafta5-Perşembe-10:30-11:20-3-3-3-ENM361-pazarlama-prof.dr.nurettinpariltili-D404 hafta5-Perşembe-12:30-13:20-2-3-3-ENM252-davranis.bilimleri-doc.dr.haticedemirbas-D406 hafta5-Perşembe-13:30-14:20-2-3-3-ENM252-davranis.bilimleri-doc.dr.haticedemirbas-D406 hafta5-Perşembe-17:30-18:20-3-2-1-ENM312-uretim.planlama.ve.stok.kontrol-doc.dr.h.edizatmaca-D409 hafta5-Perşembe-18:30-19:20-3-2-1-ENM312-uretim.planlama.ve.stok.kontrol-doc.dr.h.edizatmaca-D409 hafta5-Cuma-10:30-11:20-3-3-3-ENM369-is.analizi.ve.degerlendirme-prof.dr.mustafakurt-D404 hafta5-Cuma-11:30-12:20-3-3-3-ENM369-is.analizi.ve.degerlendirme-prof.dr.mustafakurt-D404 hafta5-Cuma-12:30-13:20-3-3-3-ENM369-is.analizi.ve.degerlendirme-prof.dr.mustafakurt-D404 hafta6-Sal1-08:30-09:20-2-1-2-ENM224-imal.usulleri-doc.dr.adnanakkurt-D414 hafta6-Sal1-09:30-10:20-2-1-2-ENM224-imal.usulleri-doc.dr.adnanakkurt-D414 hafta6-Sal1-10:30-11:20-2-1-2-ENM224-imal.usulleri-doc.dr.adnanakkurt-D414 hafta6-Çarşamba-17:30-18:20-3-1-1-ENM312-uretim.planlama.ve.stok.kontrol-prof.dr.ertanguner-D404 hafta6-Çarşamba-18:30-19:20-3-1-1-ENM312-uretim.planlama.ve.stok.kontrol-prof.dr.ertanguner-D404 hafta7-Sal1-08:30-09:20-2-2-1-ENM224-imal.usulleri-doc.dr.adnanakkurt-D414 hafta7-Sal1-09:30-10:20-2-2-1-ENM224-imal.usulleri-doc.dr.adnanakkurt-D414 hafta7-Sal1-10:30-11:20-2-2-1-ENM224-imal.usulleri-doc.dr.adnanakkurt-D414 hafta9-Sal1-08:30-09:20-2-1-3-MM226-muhendislik.mekanigi-ogr.gor.tuncapatay-D414 hafta9-Sal1-09:30-10:20-2-1-3-MM226-muhendislik.mekanigi-ogr.gor.tuncapatay-D414 hafta9-Sal1-10:30-11:20-2-1-3-MM226-muhendislik.mekanigi-ogr.gor.tuncapatay-D414 
Tablo 17. Senaryo-3 için telafi ders programı (Makeup Course Program for Scenario-3) hafta7-Pazartesi-08:30-09:20-2-1-2-ENM202-yoneylem.arastirmasi.1-doc.dr.mehmetatak-D406 hafta7-Pazartesi-08:30-09:20-2-2-1-ENM202-yoneylem.arastirmasi.1-doc.dr.feyzanarikan -D409 hafta7-Pazartesi-08:30-09:20-2-1-1-ENM202-yoneylem.arastirmasi.1-prof.dr.bilaltoklu-D408 hafta7-Pazartesi-09:30-10:20-2-1-2-ENM202-yoneylem.arastirmasi.1-doc.dr.mehmetatak-D406 hafta7-Pazartesi-09:30-10:20-2-2-1-ENM202-yoneylem.arastirmasi.1-doc.dr.feyzanarikan -D409 hafta7-Pazartesi-09:30-10:20-2-1-1-ENM202-yoneylem.arastirmasi.1-prof.dr.bilaltoklu-D408 hafta7-Pazartesi-11:30-12:20-2-2-2-ENM202-yoneylem.arastirmasi.1-yrd.doc.dr.muratarikan-D411 hafta7-Pazartesi-12:30-13:20-2-2-2-ENM202-yoneylem.arastirmasi.1-yrd.doc.dr.muratarikan-D411 hafta7-Sal1-08:30-09:20-2-1-3-ENM206-diferansiyel.denklemler-prof.dr.fatmaayaz-D414 hafta7-Sal1-09:30-10:20-2-1-3-ENM206-diferansiyel.denklemler-prof.dr.fatmaayaz-D414 hafta7-Sal1-10:30-11:20-2-1-3-ENM206-diferansiyel.denklemler-prof.dr.fatmaayaz-D414 hafta7-Sal1-12:30-13:20-2-2-2-ENM224-imal.usulleri-doc.dr.adnanakkurt-D407 hafta7-Sal1-13:30-14:20-2-2-2-ENM224-imal.usulleri-doc.dr.adnanakkurt-D407 hafta7-Sal1-14:30-15:20-2-2-2-ENM224-imal.usulleri-doc.dr.adnanakkurt-D407 hafta7-Cuma-11:30-12:20-2-2-1-ENM208-muhendislik.istatistigi-doc.dr.ugurozcan-D409 hafta7-Cuma-12:30-13:20-2-2-1-ENM208-muhendislik.istatistigi-doc.dr.ugurozcan-D409 hafta7-Cuma-13:30-14:20-2-2-1-ENM208-muhendislik.istatistigi-doc.dr.ugurozcan-D409 